\title{
Caught Between the Spectacular and the Vernacular: The Illusory Demos of the Popular Music Museum
}

\author{
CHARLES FAIRCHILD
}

\begin{abstract}
Popular music museums seek to produce a particular version of an ideal demos by explicitly constructing and articulating a collective understanding of popular music made material through rich, cross-media, sensory environments. In recent years, the pursuit of these goals has been carried out through the construction of extensive collections of high-tech displays set in high-profile buildings in the presumed Emusical capitals ${ }^{1}$ of the world, such as Los Angeles, Liverpool, and Nashville. However, while some research has begun to consider the politics that fills the displays and exhibitions of these institutions, none has yet looked at the politics that built the museums themselves. This article shows that most major popular music museums are part of larger entertainment districts whose development has coursed along the exclusionary lines of neoliberal politics and economics. As such they produce a foundational disjuncture between the strategic deployment of the vernacular elements of popular music practice and experience as codified within a demonstratively spectacular logic of visual, aural, and material display. These institutions demand the translation of the demotic experience of musical sociality into spectacular environments in ways that must be compelling enough to obscure the tensions produced their material foundations and development.
\end{abstract}

\section{Introduction}

When you approach Seattle's Experience Music Project (EMP), created by Microsoft co-founder Paul Allen, you are confronted with a building that looks like a wildly colorful smashed guitar. Bulging, undulating panels of pink, blue, and silver metal glow and shimmer even in the seemingly perpetual Seattle gloom. (Figs. 1 and 2) You enter the building through the distractingly complex foyer of this Frank Gehry building and upon reaching the exhibits on the second floor you are confronted by an imposing sight: the "Sky Church." As the EMP's guidebook tells us:

Jimi Hendrix used the term "Sky Church" to describe a place where people of all ages, cultures and backgrounds could come together to worship, learn and share a sense of communion through music. EMP uses its own Sky Church as a grand meeting hall and gathering place. ${ }^{1}$

This gathering space is dominated by what the EMP describes as the largest indoor LED screen in the world. Throughout the day, films about a variety of subjects related to popular music play continuously on this remarkably well-proportioned screen. The "Sky Church" is a technological marvel. It is wired into a prodigious technical infrastructure of which this institution is inordinately proud. ${ }^{2}$ And yet, it is somewhat disorienting to hear musicians reflecting on the personal and intimate details of their lives

\footnotetext{
${ }^{1}$ Experience Music Project, the experience (Seattle: Experience Music Project, 2000), n.p.

${ }^{2}$ Experience Music Project, the building (Seattle: Experience Music Project, 2000), n.p.
} 
and careers on a screen roughly the size of a three-story house. The reminiscences of musicians or archival clips of the small passing moments of various regional American music scenes appear lost among the spectacular trappings of the EMP.

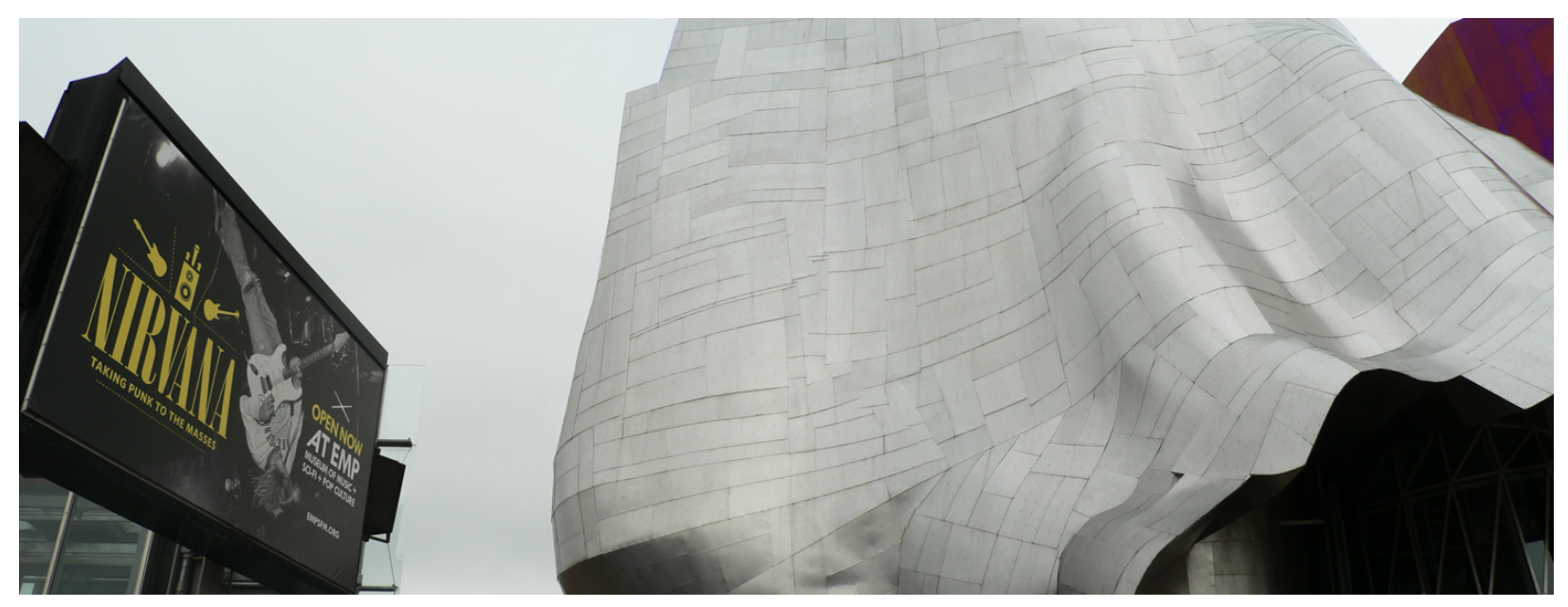

Figure 1: Experience Music Project, Seattle. Photo by author.

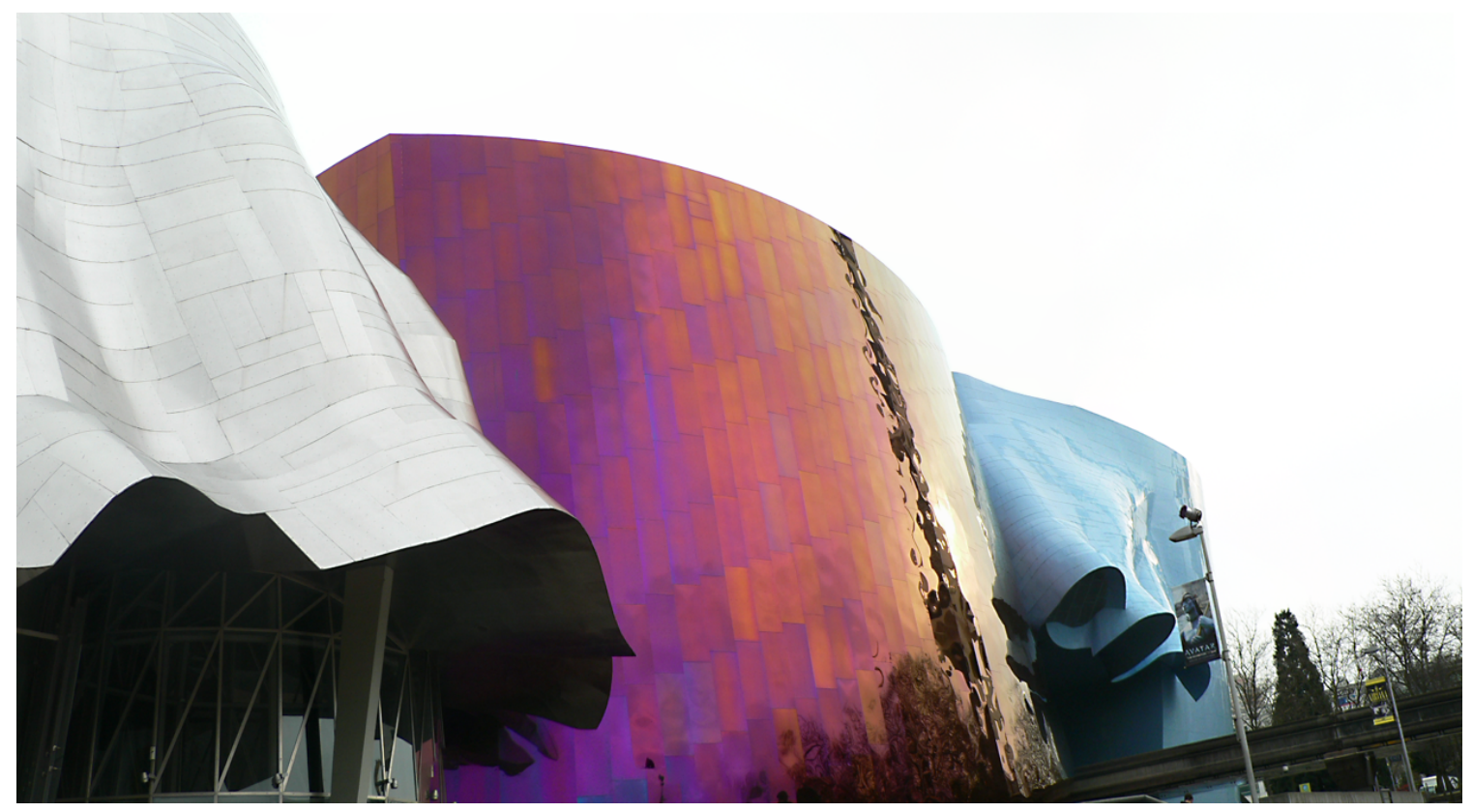

Figure 2: Experience Music Project, Seattle. Photo by author.

This scene, with its celebrity architect, intimidating media infrastructure, and intimations of cultural communion, provides us with a solid if not primal ground to explore the nature of the contemporary popular music museum. On the one hand, we are presented with the nuts and bolts of American popular music: the gigs, the fans, the guitars, the nostalgia. On the other, we experience these materials within an enveloping material and experiential infrastructure that exerts the power of a particularly "pragmatic, matter of fact" form of the spectacular. ${ }^{3}$ It is a type of spectacle that dulls the sharp edges, straightens the ethical complexity, and edges the inconvenient perspectives out of the frame. As this description of my

${ }^{3}$ Retort, “Afflicted Powers: The State, the Spectacle and September 11,” New Left Review 27 (2004): 7. 
entry into the EMP suggests, popular music museums often inhabit a complex set of tensions between their vernacular content and spectacular forms. These tensions often emerge very starkly when we examine these institutions in context and in situ by comparing them materially, politically, and historically to other similar institutions. When we do this a robust and complex story about the cultural politics they embody becomes clear.

My argument is as follows: The popular music museums examined here present their spectators with easy reveries of an unproblematic togetherness through music. Yet these institutions are the result of a specific series of exclusions of the public from their conceptualization and realization. The material resources upon which these museums were built were the result of a good deal of strategically deployed political and economic power that are part of a very specific kind of economic and urban development regime of which they are a product. This economic regime is explained below. All the popular music museums examined in this article were made possible through broadly similar forms of power that reserve the most foundational rights to shape and reshape parts of the cities in which they are set for the most wealthy and privileged. That is, those who built the precincts in which the EMP or the Country Music Hall of Fame and Museum or the British Music Experience are set were granted the power to reshape large swathes of the urban environments in Los Angeles, Nashville, London, Liverpool, Seattle, and Memphis. This has happened in markedly similar ways in each city. The public for whom these institutions have been built have only ever been offered the secondary rights of access and spectatorship, rights that can be revoked, subjected as they are to conditions which depend in each case on the specific contracts developers negotiated with public authorities to privately manage what used to be public space. In every case examined here, members of the public had no consequential role in the remaking of their own cities for the purposes of development and tourism. Yet these museums fashion themselves as places for "the people" to commune with "the music" through the extensive exhibition materials that are continually coded as demotic and vernacular. ${ }^{4}$ It seems contradictory that the exercise of these exclusive political and economic resources have resulted in the preservation of and broad access to collections of important historical materials and institutions which commonly work towards increasing this access across a wide range of people. Recently, there has been a surge of academic work which closely examines how the displays and exhibits within popular music museums are filled and how these institutions serve their broad publics in a variety of ways. However, this work has done little to explore the politics how these places got built in the first place. ${ }^{5}$ As such, this is a phenomenon that requires some detailed attention.

In what follows, I will focus on how a few key categories of material and historical fact can help us understand more fully the place of popular music museums in Seattle, Memphis, Nashville, Los Angeles,

\footnotetext{
${ }^{4}$ Charles Fairchild, "Transcendent Myths, Mundane Objects: Setting the Material Scene in Rock, Soul, and Country Museums," International Fournal of Heritage Studies 24, no. 5 (2018), 477-490; Charles Fairchild, "Understanding the Exhibitionary Characteristics of Popular Music Museums," Museum and Society 15, no. 1 (2017), 87-99.

${ }^{5}$ Chris Gibson and John Connell, "Music, Tourism and the Transformation of Memphis," Tourism Geographies 9, no. 2 (2007): 160-190, https://doi.org/10.1080/14616680701278505; Tara Brabazon and Stephen Mallinder, "Popping the Museum: The Cases of Sheffield and Preston," Museum and Society 4, no. 2 (2006): 96-112; Marion Leonard, "Exhibiting Popular Music: Museum Audiences, Inclusion and Social History," Fournal of New Music Research 39, no. 2 (2010): 171-181, https://doi.org/10.1080/09298215.2010.494199; Marion Leonard, “Constructing Histories Through Material Culture: Popular Music, Museums and Collecting," Popular Music History 2, no. 2 (2007): 147-167, https://doi.org/10.1558/pomh.v2i2.147; Andy Bennett, “'Heritage Rock': Rock Music, Representation and Heritage Discourse,” Poetics 37, no. 5-6 (2009): 479-489, https://doi.org/10.1016/i.poetic.2009.09.006; Les Roberts and Sara Cohen, "Unauthorising Popular Music Heritage: Outline of a Critical Framework." International Fournal of Heritage Studies 20, no. 3 (2014): 241-61, https://doi.org/10.1080/13527258.2012.750619; Amanda Brandellero and Susanne Janssen, "Popular Music as Cultural Heritage: Scoping Out the Field of Practice," International Fournal of Heritage Studies 20, no 3. (2014): 224-40, https://doi.org/10.1080/13527258.2013.779294.
} 
London, and Liverpool. These categories include the buildings that house these museums, the urban contexts in which each is set, and the ways in which these institutions fashion themselves as parts of larger networks of consumer experience. The material forms of these museums and the processes of their construction and presentation produce complex, continuing relationships with the contents they house. These kinds of relationships have been widely observed by museum scholars and others, often as symbolic disguises for unspoken or unacknowledged forms of power. ${ }^{6}$ Popular music museums, like most museums, use these forms of power to construct what they claim to be an ideal demos. The question here is this: what kind of demos is implied or enacted by these particular buildings set in these places in order to display their specific collections of objects, sounds, and images? There are two ways I will answer this question. I will examine how these places got built and also examine the self-images they project. When we do this, we find that these museums are built as one kind of institution, but fashioned and sold as a very different kind of institution.

\section{Outlining the Demos of the Popular Music Museum}

Between 1995 and 2014, ten major popular music museums were established in high-profile locations in many of the presumed "musical capitals" in the US and UK. Here I will look at those built in Seattle, Memphis, Nashville, Los Angeles, London, and Liverpool. ${ }^{7}$ These institutions are defined by expansive experiential infrastructures that work primarily through the strategic deployment of the vernacular elements of popular music practice and experience within a spectacular logic of visual, aural, and material display. Through myriad acts of display, these museums seek to act as influential intermediaries in the communication of specific sets of values and priorities in the public life of popular music. $^{8}$ These places translate the demotic experience of musical sociality into material environments constructed from the leveraging of carefully stockpiled and intertwined forms of public and private political and economic power. They have done so by participating in the appropriation of public space and money in order to build institutions who primary task is to display the tangible materials of the affective labor of artists and audiences in their exhibits. The crucial gesture mediating and holding in balance these seemingly incommensurate social formations is the pervasive yet inchoate assignation of the quality "demotic," not only to the music, but also to themselves. To do this, they must fashion themselves as the protectors and custodians of the music, music that must be of the highest standard of achievement to be worth protecting and displaying in such an elaborate manner. As a result, their exhibits must not only reflect, but embody and reenact familiar, orthodox narratives of transcendent communion and aesthetic triumph through music. ${ }^{9}$ The credibility and viability of these institutions depends largely on their ability

\footnotetext{
${ }^{6}$ Andreas Huyssen, Twilight Memories: Marking Time in a Culture of Amnesia (New York: Routledge, 1995), 15; Ivan Karp et al., eds., Museum Frictions: Public Cultures/Global Transformations (Durham, NC: Duke University Press, 2006), https://doi.org/10.1215/9780822388296; Mark Gottdiener, The Theming of America: Dreams, Media Fantasies, and Themed Environments (Boulder, CO: Westview Press, 2001).

${ }^{7}$ I have studied nine such sites for this project with the notable exception of the well-studied Rock and Roll Hall of Fame in Cleveland, Ohio. This was due to a practical lack of time and money.

${ }^{8}$ Russell Reising, “The Secret Lives of Objects: The Secret Stories of Rock and Roll: Cleveland's Rock and Roll Hall of Fame and Museum and Seattle's Experience Music Project," American Quarterly 53, no. 3 (2001): 489-510, https://doi.org/10.1353/aq.2001.0027; Charles Bergengren, "Simply Contradictory: The Rock and Roll Hall of Fame and Museum," Fournal of American Folklore 112, no. 446 (1999): 544-550, https://doi.org/10.2307/541492.

${ }^{9}$ Country Music Hall of Fame and Museum, A Visitor's Companion (Nashville, TN: Country Music Foundation, 2004); Experience Music Project, Crossroads: The Experience Music Project Collection (Seattle: Experience Music Project, 2000); Rock and Roll Hall of Fame and Museum, The Rock Pack, (New York: Universe Publishing, n.d.); Rock and Roll Hall of Fame and
} 
to mask and manage the inexorable tensions between their demonstratively spectacular infrastructures and intimately vernacular materials.

There are three key terms which can help us understand the tensions I am outlining: demos, vernacular, and spectacular. "Demos" is a complex and contested term, but as Wendy Brown has argued, it most often describes "the aspiration that the people, and not something else, order and regulate their common life through ruling themselves together." ${ }^{10}$ (p. 202) That is, a demos is meant to include everyone in the structure and processes of power. Importantly, a democratic demos is defined by equitable power relationships within which individuals and groups can exercise broadly commensurate forms of agency in a context that allows the social relationships that sustain that agency to be sustained over time. Popular music museums routinely construct a vision of such relationships in their displays. These museums implicitly and explicitly claim to reflect a universal demos which is defined by a set of complex set of social relationships that extend beyond relationships of power and necessity to include elective relationships of civic and political affinities. They do so through the display of extensive arrays of the vernacular materials of the music cultures that preceded them and reach well beyond them. These materials include objects, sounds, images, and ideas. I describe these materials as "vernacular" in order to capture the fact that they are the products of the mundane, organic social, cultural, and economic relationships of everyday life. In his wide-ranging study of the global rise of recorded music, Michael Denning makes a crucial distinction between "vernacular," "commercial" and "classical" musics. "Vernacular musics" are distinct from other types of music in that they grew, not only from markets or in marginalized relationships to what he calls an elite institutional "clerisy," but from the everyday lifeworlds of a wide range of existing communities. ${ }^{11}$ Thus, while they may share characteristics and circumstances with commercial musics and even some classical forms, they cannot be reduced to either participation in commercial markets or struggles against elite institutions. (pp. 7-9) In short, the social imprint of vernacular music is far wider than any of these concerns. Clearly there is an inherent affinity between the ideal of representing a universal demos and using vernacular means to do so.

Crucially, it is the third term of interest here, spectacular, that is also necessary to understand what I am identifying as the tensions that define these institutions. I am calling these museums' exhibits and infrastructure "spectacular" because they exist to be consumed by spectators. Despite the many generous and accessible services these institutions offer some sections of the public, their defining feature is that their visitors are constructed primarily as spectators, not citizens. As the Retort collective has colorfully argued, the spectacle is not simply a set of images or sensory experiences, but a meeting of contending forces in which "more and more facets of human sociability-areas of everyday life, forms of recreation, patterns of speech, idioms of local solidarity, kinds of ethical or aesthetic insubordination," have been subjected to "a constant barrage of images, instructions, slogans, logos, false promises, virtual realities." 12 The conflict between vernacular cultural production and its appropriation and use by more dominant social and economic powers is a defining feature of the spectacular. Popular music museums occupy a specific position in these contests. Importantly, their position is a familiar one with the history of museums. Anxieties over the capacity of the museum to either withstand or engage with the "barrage" of the spectacular to produce the forms of robust cultural citizenship with which it has long been associated

Museum, The Rock and Roll Hall of Fame: The First 25 Years (New York: Collins Design, 2009).

${ }^{10}$ Wendy Brown, Undoing the Demos: Neoliberalism's Stealth Revolution (New York: Zone Books, 2015$), 202$.

${ }^{11}$ Michael Denning, Noise Uprising: The Audiopolitics of a World Musical Revolution (London: Verso, 2017), 7-9.

${ }^{12}$ Retort, "Afflicted Powers," 8. 
have been a central subject of debate since the advent of the so-called "new" museum so well catalogued in the literature. When trying to outline the ideal demos sought and constructed by popular music museums, these comparatively recent institutions assume a fairly straightforward place in the larger historical trajectory of the museum, a history that also displays a similar tension between the vernacular and the spectacular. What is most important to understand is that the popular music museums examined here stand on a persistent fault line between popular forms of display and elite ones. We can understand these institutions better if we can understand the long and complex relationship between traditional museums and what are often referred to as "popular entertainments." In fact, the demos popular music museums seek is not too different in many fundamental respects from that of the traditional museum, while some bear important commonalities with the now established and familiar types of "new" museum.

Museums have long had to distinguish their exhibitions and displays from those of places such as the department store, world exposition, or wax museum, often by engaging in campaigns to emphasize the inherent educational value of museums or their ability to confer elevated social status on their select publics. ${ }^{13}$ Yet, despite a public rhetoric of enhanced status and moral solidity, the publics to which museums often had to appeal were rarely as distinct as their advocates liked to suggest. As such, the links between the public museum and popular entertainments have long been apparent. ${ }^{14}$ Specifically, there have been longstanding and significant overlaps between the visual cultures of museums and popular entertainments as well as the ways in which each institutional type addressed their presumed publics. ${ }^{15}$ The recent appearance of numerous popular music museums has been part of the continuation of the tensions between these two broad institutional types. As much contemporary scholarship has shown, the "new museum" has been the result of a broad range of complex and economic and social demands that required ever increased levels of public relevance and economic sustainability from museums. These pressures have pushed traditional museums and "popular entertainments" closer together and produced new forms of museum practice marked by an increased reflexivity and sensory enticement in displays and exhibitions. ${ }^{16}$ It has also produced an often intense focus on the production of new kinds of consumer experiences rather than traditional kinds of museum subjects. ${ }^{17}$ Importantly, the new museum is selfconsciously inclusive of a public already expected to be well-skilled in moving through complex

\footnotetext{
${ }^{13}$ Tony Bennett, The Birth of the Museum: History, Theory, Politics (New York: Routledge, 1995); Tony Bennett, "Exhibition, Difference, and the Logic of Culture," in Museum Frictions: Public Cultures/Global Transformations, 46-69; Alison Griffiths, Wondrous Difference: Cinema, Anthropology and Turn-of-the-Century Visual Culture (New York: Columbia University Press, 2002), https://doi.org/10.1215/9780822388296-003; Michelle Henning, Museums, Media and Cultural Theory (Maidenhead, UK: Open University Press, 2006); Barbara Kirshenblatt-Gimblett, "Exhibitionary Complexes," in Museum Frictions: Public Cultures/Global Transformations, 35-45, https://doi.org/10.1215/9780822388296002.

${ }^{14}$ Paul Greenhalgh, "Education, Entertainment and Politics: Lessons from the Great International Exhibitions," The New Museology, ed. Peter Vergo (London, Reaktion Books, 1989), 74-98; Kevin Hetherington, Capitalism's Eye: Cultural Spaces of the Commodity (New York: Routledge, 2007).

${ }^{15}$ Griffiths, Wondrous Difference: Cinema, Anthropology and Turn-of-the-Century Visual Culture; Mark Sandberg, Living Pictures, Missing Persons: Mannequins, Museums, and Modernity (Princeton, N.J.: Princeton University Press, 2003). ${ }^{16}$ Kylie Message, New Museums and the Making of Culture (Oxford, UK: Berg, 2006); Kylie Message, "The New Museum," in Theory, Culture and Society 23, no. 2-3 (2006): 603-6, https://doi.org/10.1177/0263276406023002110; Peter Vergo, The New Museology; Andrea Witcomb, Re-imagining the Museum: Beyond the Mausoleum (London: Routledge, 2003), https://doi.org/10.4324/9780203361023; Simon Knell, Suzanne MacLeod, and Sheila Watson, eds., Museum Revolutions: How Museums Change and Are Changed (London: Routledge, 2007); Max Ross, "Interpreting the New Museology," Museum and Society 2, no. 2 (2004): 84-103.

${ }^{17}$ Henning, Museums, Media and Cultural Theory; Charles Smith, "Museums, Artefacts, and Meanings," in The New Museology, 19-21; Beryl Graham and Sarah Cook, Rethinking Curating: Art After New Media (Cambridge, MA: The MIT Press, 2010); Roy Ballantyne and David Uzzell, "Looking Back and Looking Forward: The Rise of the Visitor-Centered Museum," Curator: The Museum Journal 54, no. 1 (2011): 85-92, https://doi.org/10.1111/i.2151-6952.2010.00071.x.
} 
economies of attention and experience. The new museum is by definition a directly engaging multimedia environment that makes ever-increasing sensory demands on its visitors and whose mode of address bears more than a passing relation to those made to shoppers and to those seeking the spectacular popular entertainments now on offer in nearly every major downtown entertainment district one can find.

By their settings and exhibitionary agendas, we can place popular music museums in the history of museum practice along this historical trajectory. These museums display the sounds, images, and objects of what they routinely advertise as "your music" or "the music of our lives." (Figs. 8 and 9) "We" are constituted as an inherent part of a collective musical past is most often front and center in these institutions' campaigns of self-fashioning. One of the main goals of the exhibits in popular music museums then, is to place museum visitors within the larger social formation they are expected to imagine themselves within already. This demands a broadly construed validation and justification for the shape and tenor of the exhibitions through the common deployment of the transcendent myths of "the music." As such, they are not the somewhat idealized "differencing machines" imagined by some scholars. ${ }^{18}$ Instead, they are fairly traditional if not conservative iterations of contemporary museum practice, mostly presenting themselves as entirely naturalized frames for their largely familiar materials which are mostly posited as loyal representations of a wider musical world. As such, popular music museums are caught between the demands of the market and the appeal of the past, trying to recapture a spectacular moment through a vernacular object, appearing to approach, but never quite reaching the open, polyvocal condition of what one scholar has somewhat dreamily called "the post-museum." ${ }^{\text {"I }}$ Instead, while these museums do offer "new" means of communicative connection and mediation, they also act to confirm the longrecognized functions of the museum as an institution of civic and social prescription and instruction. ${ }^{20}$

Importantly, the particular forms of education and prescription found in popular music museums sit very comfortably with the role and work of corporate cultural intermediaries in the music industry whose primary task has also been to produce the same kinds of ideal musical subjects through similar forms of perceptual training and instruction. As I have noted extensively elsewhere, the brokers of those salutary forms of feeling, knowledge, and connection produced through the affordances of music have long focused on defining the terms of the contests waged by people over the meaning and value of music in circumstantially specific ways. ${ }^{21}$ In their publicity campaigns, these museums continuously recall what is presumed to be a universally available collective past with which we are expected to feel an undeniable connection and allegiance. Part of the pull is how prosaic these displays can be while simultaneously cloaking their subjects in a form of artistic transcendence that is expressed and reiterated at regular

\footnotetext{
${ }^{18}$ Bennett, "Exhibition, Difference, and the Logic of Culture," 46, https://doi.org/10.1215/9780822388296-003.

${ }^{19}$ Eilean Hooper-Greenhill, Museums and the Interpretation of Visual Culture (London: Routledge, 2000); see also Chris Bruce, "Spectacle and Democracy: Experience Music Project as a Post-Museum," in New Museum Theory and Practice: An Introduction, ed. Janet Marstine (Malden, MA: Blackwell, 2006), 129-51, https://doi.org/10.1002/9780470776230.ch5.

${ }^{20}$ Message, "The New Museum," 605.

${ }^{21}$ Charles Fairchild, Danger Mouse's The Grey Album (New York: Bloomsbury Academic, 2014), https://doi.org/10.5040/9781501305962; Charles Fairchild, "Popular Music," in The Cultural Intermediaries Reader, eds. Jennifer S. Maguire and Julian Matthews (London: SAGE, 2014), 125-33, https://doi.org/10.4135/9781473912281.n12; Charles Fairchild, Music, Radio and the Public Sphere: The Aesthetics of Democracy (Basingstoke, UK: Palgrave, 2012), https://doi.org/10.1057/9780230390515; see also Georgina Born, "On Musical Mediation: Ontology, Technology and Creativity," Twentieth-Century Music 2, no. 1 (2005): 7-36, https://doi.org/10.1017/S147857220500023X; Nick Prior, "Critique and Renewal in the Sociology of Music: Bourdieu and Beyond," Cultural Sociology 5, no. 1 (2011): 121-138, https://doi.org/10.1177/1749975510389723; Antoine Hennion, "Music and Mediation: Toward a New Sociology of Music," in The Cultural Study of Music: A Critical Introduction, eds. M. Clayton et al. (London: Routledge, 2003), 80-91.
} 
intervals. ${ }^{22}$ These displays provide tangible pieces of the collective illusion of a form of communion they themselves produce. While each demos we are asked to inhabit may be imagined slightly differently, they make the same general demands on us. They ask us to encounter these complex assemblages of preexisting materials and organize our senses and attention in order to respond in expected ways. These museums are intimately connected both directly and indirectly to broader forms of economic, cultural, and political power, and accumulation that define our historical era. Despite the geographic spread of the examples that follow, they all exhibit marked similarities in how they participate in larger spheres of political and cultural power.

\section{The Place and the "Non-Place" of the Popular Music Museum}

In order to understand more fully the kinds of places these institutions are, we need to understand the animating social and ideological dynamics that have made them possible. On the one hand, all the institutions examined here are integral parts of urban districts that are designed to encourage what Silk and Andrews call "consumption-intensive capital accumulation." These districts are intended to facilitate what they call "the physical and symbolic reconstitution of select parcels of America's [sic] urbanscape into spectacular, multifaceted environments." These museums are pieces of larger efforts to transform areas regarded by planners and developers as derelict or obsolete into trendy, gentrified manifestations of an ersatz heritage made safely present and continuous with a presumed collective past. ${ }^{23}$ On the other hand, these museums are also heavily populated with a vast range of aural and visual materials appropriated from the vernacular traditions whose lineages they seek to celebrate and whose meanings they seek to demarcate. The tensions produced between these two broadly contradictory characteristics make these institutions into distinctly complex places.

We can understand these tensions more effectively when we acknowledge that these museums are built as what Marc Augé would call "non-places," a spatial and social form spawned by a "supermodernity" that produces spaces of process, instability, and transience. However, they are presented to the public as what he calls "anthropological places," or what he calls "places of identity, of relations and of history." 24 Anthropological places do not reflect, exhibit, or display social life, they produce it. By contrast, non-places are those in which Augé says we encounter "the image of what we are no longer" by becoming "spectators of ourselves." 25 He argues that "as anthropological places create the organically social, so non-places create solitary contractuality." ${ }^{26}$ By this he means the user of the non-place is defined not by the social relations of everyday life, but by the social relations of the contract, or what he calls the non-place's "instructions for use." These contrast with "the unformulated rules of living know-how" that define and are enacted within anthropological places. ${ }^{27}$ Most importantly, Augé stresses the fact that the correspondence between these two kinds of places is not definitional, but rather relational. That is, a place does not simply appear and usurp the non-place or vice versa in some kind of zero sum game of social and spatial power. Instead,

\footnotetext{
${ }^{22}$ Fairchild, "Transcendent Myths, Mundane Objects: Setting the Material Scene in Rock, Soul, and Country Museums."

${ }^{23}$ Michael L. Silk and David L. Andrews, "Managing Memphis: Governance and Regulation in Sterile Spaces of Play,” Social Identities 14, no. 3 (2008): 396, https://doi.org/10.1080/13504630802102820.

${ }^{24}$ Marc Augé, Non-Places: An Introduction to an Anthropology of Supermodernity (London: Verso, 1995$), 52$.

${ }^{25}$ Augé, 55-6.

${ }^{26}$ Ibid., 94-5.

${ }^{27}$ Ibid., 101.
} 
"places and spaces, places and non-places, intertwine and tangle together." ${ }^{28}$ Places routinely emerge and evolve within non-places which can become anthropological places through the agency and exertions of the people who inhabit them, however briefly and partially. But these places can then slip just as quickly back into non-places, returning to a kind of default anti-anthropological emptiness.

The dissipation of anthropological places and the agencies that form them and circulate within popular music museums takes the elusive demos these museums may have appeared to create with them. As such, the demos these museums and the larger entertainment districts in which they sit seek to produce is illusory in part because it is not a stable entity constructed through the persistent social and political relationships grounded on a collective exertion of self-conscious agency. Rather, they are constituted through the more capricious social ties of the market. While these places continually fashion themselves as the kinds of places in which organic social relations are fostered, they nevertheless return routinely to their steady, default states, unable to hold onto any persistent traces or lasting residues of the popular agency that may have briefly transformed them. Given the intertwining of place and non-place, we should therefore understand the relationships between these buildings and their contents by seeing them as part of a larger dialectic between how these places are constructed and how they are imagined and presented. Specifically, these museums are centered around the socially sensuous, bodily, and emotional experience of popular music, but they produce experiences in which popular music rarely appears as the subject of the laborious forms of intervention and cultural intermediation that produce our understandings of it. These facets of their existence are simply not part of their insular, imagined worlds. This conceit is a defining feature of these museums. In both their settings and their contents, there is little to betray much of what has made them. As such, the primary objects of analysis here will be the economic and ideological forces that built these museums, stocked their vitrines, and populated their wall displays. A closely held secondary concern is how we are instructed to think about and experience what is in those vitrines and displays.

\section{The Material Context for an Illusory Demos}

When we look closely at the exteriors of popular music museums in Seattle, Memphis, Nashville, Los Angeles, London, and Liverpool, we are able to see the place of these institutions in the "new geographies of exclusion and landscapes of wealth" that have developed in the form of entertainment districts in each of these cities. ${ }^{29}$ These geographies and landscapes are the result of the careful and strategic use of political and economic power by states and corporations to transform selected urban districts into privately operated, secure tourism and consumption bubbles. All of these districts have been created through an economic system that political economist Aaron Schneider has called "dual development." 30 This economic model has developed since the mid-1970s as a central part of a larger model of economic development often called neoliberalism. ${ }^{31}$ In the case of cities like the ones examined here, dual development means a close focus on the tourism, services, construction, and real estate sectors in which "elites impose highly unequal terms, characterized by a few good jobs and many bad ones." 32 Schneider

\footnotetext{
${ }^{28}$ Ibid., 107.

${ }^{29}$ Mike Davis and Daniel Bertrand Monk, Evil Paradises: Dreamworlds of Neoliberalism (New York: New Press, 2007), ix.

${ }^{30}$ Aaron Schneider, Renew Orleans? Globalized Development and Worker Resistance After Katrina (Minneapolis: University of Minnesota Press, 2018)

${ }^{31}$ David Harvey, A Brief History of Neoliberalism (Oxford: Oxford University Press, 2005).

${ }^{32}$ Schneider, 2.
} 
explains that the

markets served by these sectors are international; they operate at high levels of productivity and provide opportunities for significant wealth accumulation. Yet, typical of dualist patterns, these leading sectors are disconnected from the rest of the city; provide few linkages or spillovers to stimulate other activities; provide limited employment; do little to raise levels of productivity in other sectors; and offer little in terms of raising the income or consumption of the general population. ${ }^{33}$

Schneider's very well-supported findings demonstrate that while dual development often produces high economic growth, it also produces high levels of inequality and poverty, because most of the benefits of growth benefits accrue to what economists call the "rent-seeking" activities of international investors who seek increased and predictable returns and profits drawn from the appreciation of assets, such as intellectual and physical property, without necessarily producing much beyond this. ${ }^{34}$ Importantly, Schneider concludes that "accumulation by dispossession often takes cultural form in the dispossession of the unique community cultures and practices of working classes and popular sectors" in the service of exactly these "rent-seeking" activities. ${ }^{35}$ Such cultures and practices are transformed into symbolic resources from which some measure of profit can be extracted. We will see all of these aspects of this model of economics and urban development appear in each city examined below.

These seemingly abstract economic concerns have practical and experiential consequences. These consequences often have a generally uniform cast and consequence, as Silk and Edwards explain:

The attendant presence of, in various permutations, shopping malls, themed restaurants and bars, entertainment-oriented museum and gallery installations, gentrified housing developments, conference complexes, waterfront pleasure places, and professional sport megacomplexes has, at least partially, precipitated the advancement of a new epoch in the material (re)formation of the American [sic] urban landscape. ${ }^{36}$

The places they describe are marked by the evacuation of the kinds of social and economic structures and relationships that once marked them as anthropological places and replace these with the relationships of Augé's "non-places." ${ }^{37}$ It is crucial to note that the museums analyzed here are not dominating institutions in and of themselves. Instead, these museums are one small, but symbolically potent, highprofile part of a dominant mode of urban development which prioritizes tourism and gentrification over social development. In the cases that follow below, multiple levels of government collaborated with their primary constituents, real estate developers and allied businesses, to effect the necessary harnessing of public subsidy and appropriation of public resources to provide a low risk context for investors, and eventually, consumers. These measures displaced existing residents and dismantled pre-existing communities to smooth the way ahead. These museums moved into the places left behind.

The Experience Music Project (EMP) ${ }^{38}$ is set in the Seattle Center, a 74-acre plot of land two

\footnotetext{
${ }^{33}$ Schneider, 21.

${ }^{34}$ Michael Hudson, $\mathcal{F}$ Is for Funk Economics: A Guide to Reality in an Age of Deception (ISLET Publishing, 2017).

${ }^{35}$ Schneider, 33.

${ }^{36}$ Silk and Andrews, 396.

${ }^{37}$ Augé, Non-Places: An Introduction to an Anthropology of Supermodernity.

${ }^{38}$ The Experience Music Project is the original name of this museum. In 2004, it incorporated the Science Fiction and Fantasy Hall of Fame originally set in Kansas City and devoted part of its exhibition space to science fiction. The new name was The Experience Music Project and Science Fiction Museum and Hall of Fame. The current name, changed in 2016, is The Museum of Pop Culture, or MoPOP. When I conducted this research, I only visited the music side of the museum which was called The Experience Music Project. Therefore, I have used this name for the sake of continuity and clarity.
} 
kilometers northwest of downtown that is the product of long tradition of central planning by American urban elites besotted by their own visions of the future. This land was the site of the 1962 World's Fair, known as the "Century 21 Exposition." It still sports the photogenic Space Needle and the once-futuristic monorail. In order to pave the way for "the future," the city bulldozed large swathes of two of Seattle's less wealthy neighborhoods in $1961 .^{39}$ In a broadly enthusiastic paean to "progress," one local historian noted that the Warren Avenue and South Queen Anne neighborhoods had few defenders:

The newspapers reported the historic carnage with enthusiasm: It meant progress toward the much anticipated fair... There was comparatively little outcry from the public, no landmarks process or historic districts to protect significant structures. By and large, the Warren Avenue neighborhood was considered blight... Slum clearance was thought to be good urban policy. ${ }^{40}$

Since its creation, this parcel of land has become a routine repository of varied and repeated planning efforts all supported through public subsidy and the friendly debt of publicly issued bonds to facilitate its maintenance and development. These periodic spasms of civic virtue have resulted in the gradual closing off of the district behind the virtual walls of high-profile, high-priced venues and attractions, few of which contribute to the costs of administering the area despite substantial public support. ${ }^{41}$ The gleaming colorful masses of the EMP sit uncomfortably on the boundary of a part of the city long known for its physical and economic disconnection from its surroundings. (Figure 3)

There are several persistent conceptual commonalities evident between the 1962 World's Fair and the EMP, built in 2000, that are telling not only for understanding this museum, but the others examined here as well. First, both were the results of elite planning sold through brash promises of wealth and prosperity for all. In each case, planners pushed a vision of a future that was inclusive and would be produced through the grand achievements of social uplift made possible through open and accessible educational endeavors that were closely linked to science and technology. Second, in each case, Seattle's planners were pushing back against a sense of the city's own perceived immaturity and marginality. As one contemporary observer of the World's Fair noted just after planning for the event had begun, the city's elites hoped that the exposition would "change the national image of Seattle from that of a rainsoaked sawmill town surrounded by Indian reservations to the modern gateway to the Orient." ${ }^{2}$ This Seattle, he said, was "comfortable on her hills" and was "triumphant over neighbors who once dreamed they could break her."

\footnotetext{
${ }^{39}$ Knute Berger, "Seattle Center: How the City Bulldozed History to Create Change," Crosscut, May 19, 2011, accessed September 18, 2015, http://crosscut.com/2011/05/seattle-center-how-city-bulldozed-history-create-c/.

${ }^{40}$ Berger, "Seattle Center."

41 “At 50th Anniversary of World's Fair, Seattle Center Continues to Evolve," Brandon Sun, June 16, 2012, accessed September 18, 2015, http://www.brandonsun.com/weekend/at-50th-anniversary-of-worlds-fair-seattle-center-continues-toevolve-159248685.html?thx=y; Stuart Eskenazi, “City to spend up to $\$ 650 \mathrm{~m}$ on Seattle Center revamp," The Vancouver Sun, February 27, 2008, B2.; Associated Press, "Debt-ridden Seattle Center Drains City Funds," Columbian, November 8, 2004: C4; Seattle Center, Drawn to the Center: Seattle Center Century 21 Master Plan (Century 21 Committee: Seattle, Washington, 2008).

${ }^{42}$ Murray Morgan, Skid Road: An Informal Portrait of Seattle (New York: Viking Press, 1960), 276.

${ }^{43}$ Morgan, 276.
} 


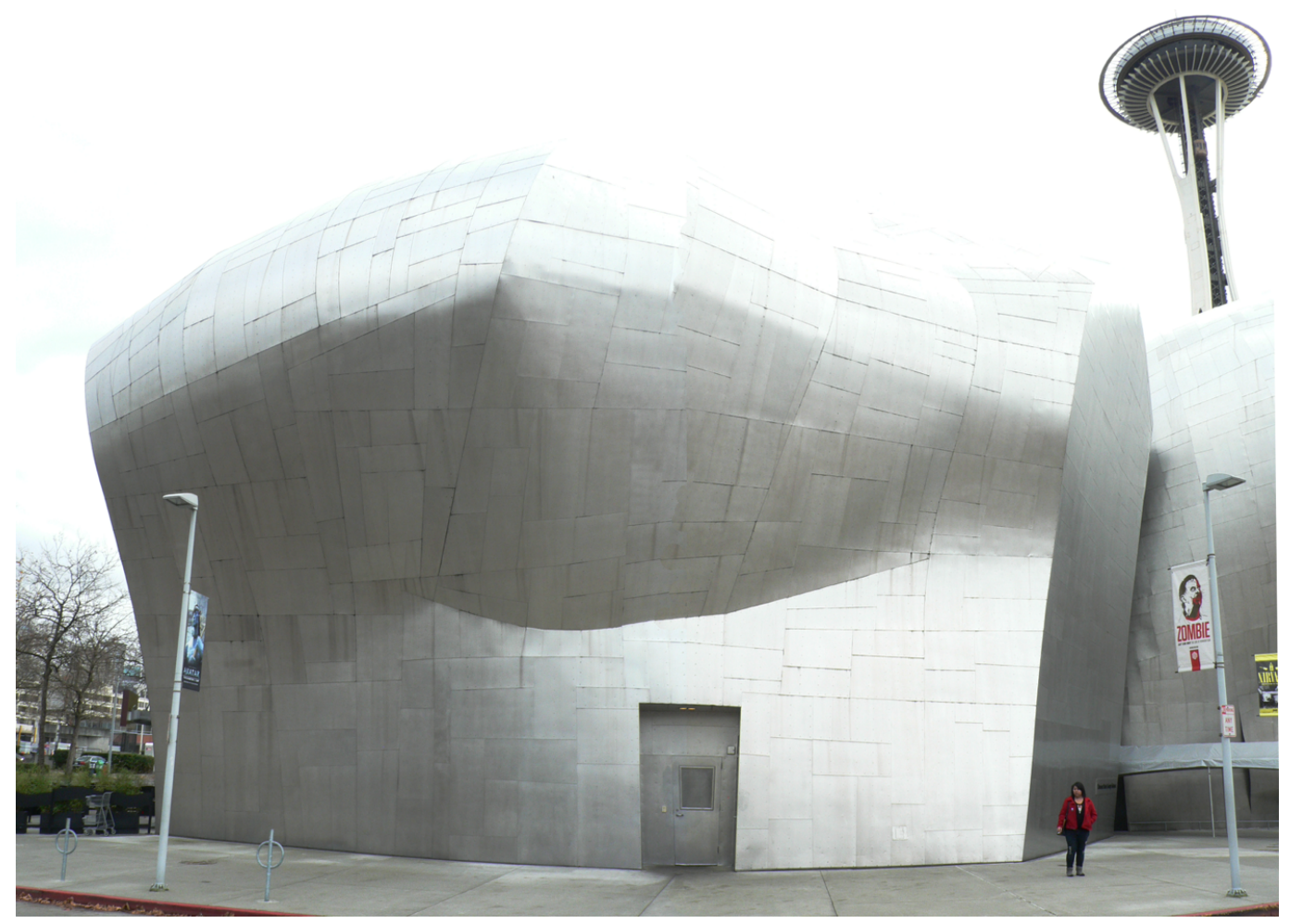

Figure 3: Experience Music Project, Seattle. Photo by author.

Just as the World's Fair made the city's elite's feel more "mature" at their own "glittering projection of life in the year 2000," ${ }^{44}$ so too has the EMP's Gehry-designed building offered the city an iconoclastic, "world class" architectural statement. ${ }^{45}$ The slightly too rapturous official choruses of support that greeted both projects suggests a problem of maturity that persists across the decades that separate them.

Consonant with visions of a harmonious future defined by the popular blessings of science and technology, the EMP has also routinely sold itself as an open forum for participation in the social life of the city and the attendant social uplift this would produce. Among its own stream of intemperate claims was the claim to be not only reflecting, but inspiring and shaping, the music of the future. It did so in part through its own grand projections of 800,000 visitors per year, most of whom would clearly be expected to partake in some form of museum-sponsored tutelage. ${ }^{46}$ Education, outreach, and musical practice were central themes in the EMP's initial salvos of public relations upon its very grand opening in 2000 across the range of magazine and newspaper articles chronicling the event. Co-founders Paul Allen and his sister Jodi Patton explained that the goal of the project "is built around trying to get people involved in making and experiencing music." ${ }^{\prime 7}$ Patton argued that her "goal at the highest level is to have people leave with a better understanding of how music affects them-how it affects their lives and history and how they fit into that world. My great hope is that they go out and motivate others to contribute and inspire." ${ }^{28}$ One museum project manager suggested that the goal of the Sound Lab, where visitors can play a variety of computerized musical instruments, "was to give people the experience of playing music for the first time,

\footnotetext{
${ }^{44}$ Seattle World's Fair, Century 21 Exposition Guide, 1962, accessed May 26, 2016, http://digitalcollections. lib.washington.edu/cdm/compoundobject/collection/ptec/id/3769.

${ }^{45}$ James Russell, “A Marriage of Money, Technology, Youth Culture, and Glitz,” Architectural Record 188, no. 8 (2000): 126.

${ }^{46}$ Noe Gold, "Experience This," Hollywood Reporter, June 13, 2000, 23.

${ }^{47}$ Brett Atwood, "Music Museum Due: Online Exhibit Bows," Billboard 111 (1999): 1, 78.

${ }^{48} \mathrm{EMP}$, the experience, 10.
} 
without going into a music store, trying to play Led Zeppelin and being intimidated by the salesman." ${ }^{49}$ Neil Strauss reported back for the New York Times that the Sound Lab was the EMP's best feature. Visitors can "adjust the separate tracks of "Sweet Dreams" by the Eurythmics on a mixing board as a studio engineer does." He noted parenthetically that on opening day, "one visitor mixing the song was surprised to find Dave Stewart of the Eurythmics, a friend of Mr. Allen's, reaching over his shoulder to help him." ${ }^{50}$ Curator Chris Bruce argued that "if you can inspire the Jimi Hendrix of the future, you've done your job." ${ }^{11}$

Neither the Exposition and the resultant Seattle Center nor the EMP has lived up to their rather immodest promises. The Seattle Center has long been accused of failing to integrate into its immediate surroundings, a failure that was a result of design as much as circumstance. As one history of the area noted, planners treated the World's Fair as an opportunity "to experiment with urban planning in order to improve the appearance of downtown, protect property values, and prevent the spread of the "slum conditions" that threatened to make Seattle like eastern cities." 52 The original district surrounding the fair precinct was regarded as the antithesis of both the central city and the region's suburbs. Parts of the area were said to have "resisted prosperity" after earlier elite planning efforts failed to produce the desired effects. ${ }^{53}$ The development of the Seattle Center did not produce the improvements the city's leaders sought. Instead, "in its urban detachment, the Seattle Center resembled such suburban enclaves as the shopping mall and the theme park," exactly as its planners had intended. ${ }^{54}$ In recent decades, the Seattle Center has been touted as a center of activity and participation in the civic life of the city while also being consistently mired in a string of abandoned plans to revitalize and rejuvenate the costly facility. ${ }^{55}$

Despite the repeated investments the city has made in the Seattle Center, the city continues to suffer the characteristic outcomes of dual development. Tourism has been booming in the city for nearly twenty years, but so have poverty and homelessness, ${ }^{56}$ economic inequalities that result from wages being kept aggressively low in large areas of employment. This is due in part to ways in which investment has been directed towards a small range of industries that tend to produce more in "rents," or returns on the appreciation of assets, than on more widely beneficial investments. And it is in this circumstance that we can see quite vividly the idealized image of the EMP as an "anthropological place" of musical practice abutting its simultaneous status as a non-place constructed to appeal to transient populations of tourists and restless investors. The museum does indeed inspire and excite. Their visitor numbers and service to the community seem solid. ${ }^{57}$ Yet this cuts both ways. The EMP is part of a complex of symbolically effective images about Seattle that, when sold to the wider world, ${ }^{58}$ drive the very dual development that undermines the communities that produced much of the music the museum celebrates.

\footnotetext{
${ }^{49}$ David Fricke, “The \$240 Million Temple of Rock: Paul Allen’s Experience Music Project Opens in Seattle,” Rolling Stone, July 6-20, 2000, 48.

${ }_{50}^{5}$ Neil Strauss, "Making a Museum Out of Music, Part 2," New York Times, June 26, 2000, E1+.

${ }^{51}$ Strauss, E4.

52 John Findlay, “The Off-Center Seattle Center: Downtown Seattle and the 1962 World's Fair," The Pacific Northwest Quarterly 80, no. 1 (1989): 5.

${ }_{53}^{53}$ Findlay, 5.

${ }^{54}$ Ibid., 10.

55 Seattle Center, Drawn to the Center; Susan Kelleher and Emily Heffter, "Goodbye to grand plan for Seattle Center?," Seattle Times, March 17, 2010, accessed April 3, 2010, http://www.seattletimes.com/seattle-news/goodbye-to-grand-plan-for-seattlecenter/.

${ }^{56}$ Francesca Murnan, Understanding King County Racial Inequalities (United Way of King County, 2015).

${ }^{57}$ Museum of Popular Culture (MoPOP), 2016 Report to Our Community (Seattle: Museum of Popular Culture, 2016).

${ }^{58}$ James Lyons, Selling Seattle: Representing Contemporary Urban America (London: Wallflower Press, 2004).
} 
Nearly identical phenomena can be found in Memphis. These are also founded on the city's musical patrimony, in this case, the city's self-proclaimed mythological status as the fount from which all contemporary American popular music has sprung. The official Memphis tourism guide presents it to us like this:

If Memphis music moves you, how will you feel at its source? Energized, as you dance at the Stax Museum of American Soul Music? (There's space designated, so bring your moves.) Starstruck, rolling through the gates of Graceland? Reverent, inside Sun Studio while hanging with the spirit of Elvis, Johnny Cash and Rufus Thomas? (Check the addition of the DJ booth Dewey Phillips used to broadcast Elvis for the first time. Ever.) Heady, walking Beale Street to the Memphis Rock 'n' Soul Museum? That's about the time it'll hit you-how deep Memphis music runs, how it connects us all and how it lives on today. ${ }^{59}$

Again, we see an appeal to an anthropological understanding of place, a place of innate social and historical connection linking the past to the present.

The primary material form of this engagement comes through the once-reviled but now-sainted Beale Street corridor and the adjacent Peabody Entertainment District, which both occupy most of the southern end of the downtown. Beale Street has been justly celebrated, not only as a particularly vibrant corridor of commercial activity, but as a socially and historically important place through which powerfully influential aspects of African American culture developed for nearly a century. ${ }^{60}$ After the riots following the assassination of Martin Luther King Jr, in 1968, the existing processes of "white flight," deindustrialization, and the deskilling of lower paid workers were exacerbated, not just in Memphis, but across the entire region. ${ }^{61}$ Typical descriptions of the transformation of Beale Street from an African American business district in a violently segregated city to an influential example of heritage tourism typically describe the neighborhood as a "wasteland" prior to gentrification. ${ }^{62}$ Over several decades beginning in 1980, the area around Beale Street has seen nearly all of the existing buildings replaced by the familiar array of building renovations and conversions, hotels, the construction of several purpose-built sports stadiums, and themed restaurants mostly housed in buildings that are only intended to recall the district's past through their size and ornamentation. The literal reconstruction of the four blocks of Beale Street that are now the primary tourist attraction are seamlessly connected to the larger Peabody Entertainment District containing FedEx Forum basketball arena, the AutoZone Park baseball stadium, and several other attractions.

\footnotetext{
${ }^{59}$ Memphis Travel, Memphis Map and Travel Guide (Memphis, TN: Memphis Travel, 2015), 4.

${ }^{60}$ Preston Lauterbach, Beale Street Dynasty: Sex, Song, and the Struggle for the Soul of Memphis (New York: W.W. Norton, 2015).

${ }^{61}$ David Smith, “"Memphis Died with Dr King,” The Guardian, April 2, 2018.

${ }^{62}$ Cathryn Stout, "John Elkington and the Remaking of Beale Street," Southern Cultures 21, no. 3 (2015), 103-10; John

Elkington, Beale Street: Resurrecting the Home of the Blues (Charleston, SC. The History Press, 2008).
} 


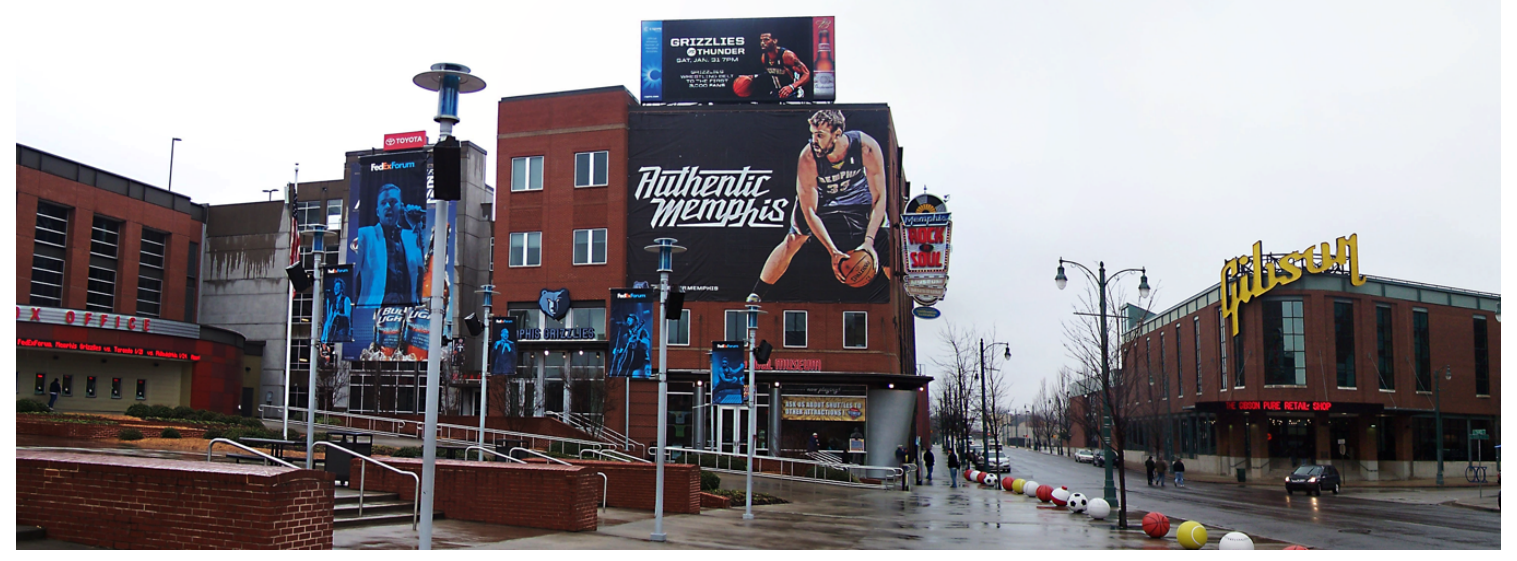

Figure 4: FedEx Forum, Memphis. Photo by author.

As with many cities across the American South, Memphis has been long subjected to forms of urban planning and municipal governance that entrenched the power of industrial interests and economic elites. ${ }^{63}$ This power has resulted in swathes of the historic city being periodically wiped away for various development and urban "renewal" projects. The music-themed gentrification of Beale Street has become the conceptual anchor for the perpetually approaching renaissance of the city. Next to the basketball arena sits the Smithsonian-affiliated Memphis Rock and Soul Museum. Its placement at the edge of a jumbled plaza renders it nearly invisible, overshadowed as it is by billboards and by the Gibson Guitar Factory sign across the street. (Figure 4) As with the EMP, however, Beale Street's musical attractions are presented to the public, not as part of "a simulated landscape of former (musical) glories," but as a primary source of communal musical experience. Boosters have continually claimed that the immediate benefits of the project serve all. As with Seattle's vision of a prosperous future, Memphis too was heir to a splendid vision of an enviable future, in this case a racially harmonious future that might put the ghosts of the region's violently segregated history to rest. However, even the most studiously neutral observers have admitted that the redevelopment of Memphis has gradually demolished the possibility of the site remaining a continuous and living African American community, replaced with "a simulated landscape of former (musical) glories, packaged for tourist consumption." While the processes of "urban renewal stimulated by cultural tourism has had negative impacts on black residents as gentrification has brought greater rents and other costs," displaced residents have been left with the comforting thought that their "heritage is belatedly being recognized and promoted more effectively." ${ }^{64}$ The efficacy of the dual development in Memphis has proved nearly identical to that in Seattle as the markers of tourism and real estate-focused development continue to define the city's economy, including ample opportunities for wealth accumulation that do little to benefit the local population who are not directly invested in them. Importantly, the specific types of poverty very nearly match those found in Seattle, with African American residents accumulating the least wealth, the fewest assets, and the lowest salaries all despite a long boom in tourism. ${ }^{65}$

\footnotetext{
${ }^{63}$ Blaine Brownell, "The Commercial-Civic Elite and City Planning in Atlanta, Memphis, and New Orleans in the 1920s," The Fournal of Southern History 41, no. 3 (1975): 339-68, https://doi.org/10.2307/2206403; Roger Biles, "Epitaph for Downtown: The Failure of City Planning in Post-World War Two Memphis,” Tennessee Historical Quarterly 44, no. 3 (1985): 267-84; Carl Abbott, The New Urban America: Growth and Politics in Sunbelt Cities (Chapel Hill: University of North Carolina Press, 1981).

${ }^{64}$ Gibson and Connell, 182-4.

${ }^{65}$ Elena Delavega, The Poverty Report: Memphis Since MLK (Memphis: National Civil Rights Museum, 2018).
} 
As with Memphis, Nashville has also created a downtown entertainment district in which musicthemed attractions, in this case the Country Music Hall of Fame and Museum and the adjacent behemoth called the Music City Center, have displaced correspondingly wide chunks of downtown. Standing at the corner of Fifth Avenue South and Demonbreun Street in the lower Broadway district, it is difficult not to feel intimidated by the scale of architectural hubris. (Figure 5) The district now consists almost entirely of sporting facilities, themed restaurants, and extensive hotel complexes produced by an extraordinary rate of gentrification. While also part of the same long-term dynamic of southern American urban governance that has shaped Memphis, Nashville's political and economic elites have recently embraced broader visions of the city more relevant to what contemporary urbanists have taken to calling "global downtowns."66

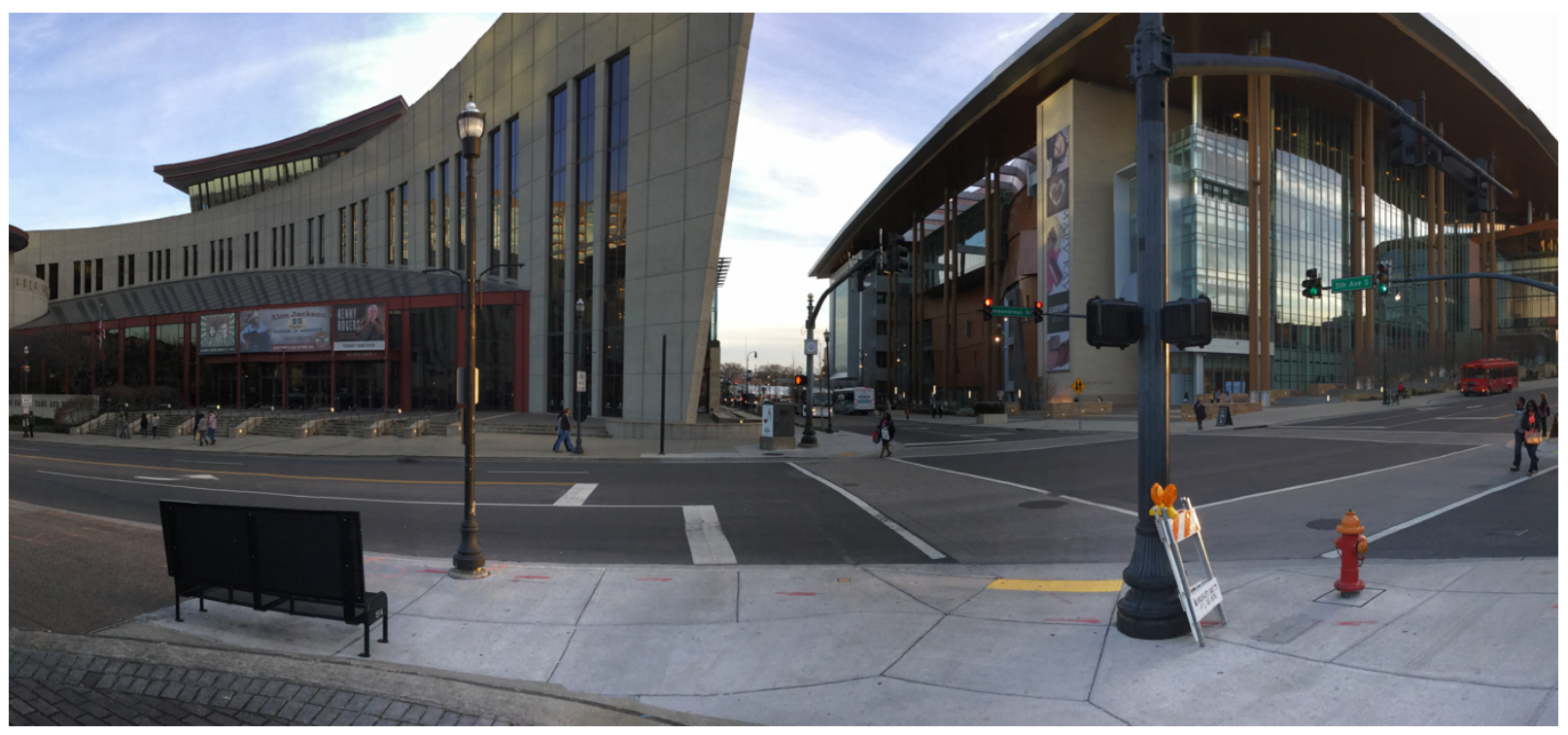

Figure 5: $5^{\text {th }}$ Avenue South and Demonbreun Street, Nashville. Photo by author.

The recent transformations wrought on Nashville's city center, according Lloyd and Christens, have been designed to service both "extravagant financial elites on the one hand and hipster creatives on the other," both demographics being suitable to the increased "attention to cultural amenities and cosmopolitan symbolism" that has shaped the city's redevelopment. ${ }^{67}$ Much of this work has followed the "dual development" pattern. It was funded by luxurious tax breaks and markedly creative debt financing devices offered to international capital markets, debt vehicles which still hang over the city. ${ }^{68}$ More directly, the state spent \$623 million on the Music City Center, \$128 million on the adjacent Omni Hotel, and crafted a special tax district to enclose the site in a three-mile radius of dispensation. ${ }^{69}$ Unlike Memphis, however, a once tightly closed shop of elite planning and city governance has given way to a more inclusive, global elite-dominated planning regime, one that is more synchronized with not just local, but also the national and global economic paradigms described by Schneider. ${ }^{70}$

\footnotetext{
${ }^{66}$ Peterson and McDonough, Global Downtowns, https://doi.org/10.9783/9780812208054.

${ }^{67}$ Richard Lloyd and Brian D. Christens, "Reaching for Dubai: Nashville Dreams of a Twenty-First Century Skyline," in Global Downtowns,116-7, https://doi.org/10.9783/9780812208054.113.

${ }^{68}$ Lloyd and Christens, 116-7.

${ }^{69}$ Bobby Allyn, "Nashville Gambles on Lure of New Convention Center," New York Times, November 20, 2012 , B8.

${ }^{70}$ Ola Johansson, "Ten People Can't Run this City Anymore: Neoliberalism and Governance Change in Nashville, Tennessee," Southeastern Geographer 47, no 2 (2007): 298-319, https://doi.org/10.1353/sgo.2007.0028; Schneider, Renew Orleans? Globalized Development and Worker Resistance After Katrina.
} 
The Country Music Hall of Fame and Museum and the Music City Center in particular are the results of this synchronization. Each, along with the adjacent Bridgestone Arena, anchored a process that has drastically changed the shape of the South Broadway district and surrounding neighborhoods. Against the arguments and influence of advocates of the "New Urbanism," who argue "against suburban sprawl, as well as against attempts to lure capital back into downtown through prefabricated entertainment destinations," both buildings have acted as justifications for the rapid transformation of downtown. What has emerged is the exact sort of "Disneyfied downtown" the New Urbanism counsels against. ${ }^{71}$ Through the forcible demolition of buildings housing such community institutions as the old Musicians Hall of Fame, forced to relocate to the other end of downtown, one disgruntled local noted that the "lower Broadway region of downtown Nashville is the last bastion of what Music City used to be. Large civic projects like the new convention center continue to gobble up landmarks and venue space that keeps the music in Music City." 72

However, it should be clear that this disgruntled commentator holds a substantially different understanding of what "the music in Music City" is for than do those charged with the continual attraction of prosperity. The January-June 2015 edition of the Nashville Visitor Guide, for example, provides us with the boisterous imagery and language that tells us what exactly "the people" communing with "the music" should look like. Throughout this 106-page tsunami of "things to do," music holds pride of place. ${ }^{73}$ It is "intricately woven into the fabric of the community" and spread throughout a tapestry of "neighborhood hot spots that offer their own hint of cultural authenticity all year round." ${ }^{\text {" We then see }}$ Brad Paisley, index finger raised in front of a frame-filling image of an American flag, panoramic shots of capacity crowds at Barbara Mandrell's Fontanel Mansion amphitheater, and the appreciative crowds at the Ryman Auditorium, as well as the Fourth of July celebrations in the Broadway Historic District. Throughout the guide, stereotypically thin platinum blonde women and roundish, bearded men ply their musical trades as small groups gazing reverently at the displays at the Country Music Hall of Fame and Museum on the opposing pages. The guide gives us a good long look at the overwhelmingly dense forms of musical sociality for which Nashville is famous, the music acting as a synecdoche for the seemingly endless forms of communion on offer.

The scale of development and rhetorical centrality of musical experience is similar in the gentrification in downtown Los Angeles. Following the dual development model, the city participated in creating L.A. Live, a brightly lit behemoth, home to The Grammy Museum, that occupies a similar downtown terrain. Its dazzling exteriors bely the complex and bitter contests fought over it for years. The building hulks like an impenetrable wall of consumerism over one of the city's famously wide, antipedestrian boulevards. (Figures 6 and 7) L.A. Live was part of a larger redevelopment of the downtown centered around art, and later, shopping and upscale residences.

\footnotetext{
${ }^{71}$ Richard Lloyd, “East Nashville Skyline,” Ethnography 12, no. 1 (2011):115, https://doi.org/10.1177/1466138110387219.

72 "Nashville Convention Center Controversy Not Over," August 28, 2010, accessed September 20, 2015, http://www.savingcountrymusic.com/nashville-convention-center-controversy-not-over; Getahn Ward, "Office Tower, Entertainment Planned at Old Nashville Convention Center Site,” The Tennessean, December 4, 2013, accessed December 28, 2015. http://archive.tennessean.com/article/20131204/BUSINESS02/312040109/Office-tower-entertainment-planned-oldNashville-Convention-Center-site.

${ }^{73}$ Nashville Visitor's Guide (Nashville, TN: Nashville Convention and Visitor's Bureau., 2015$), 8$.

${ }^{74}$ Ibid., 8.
} 


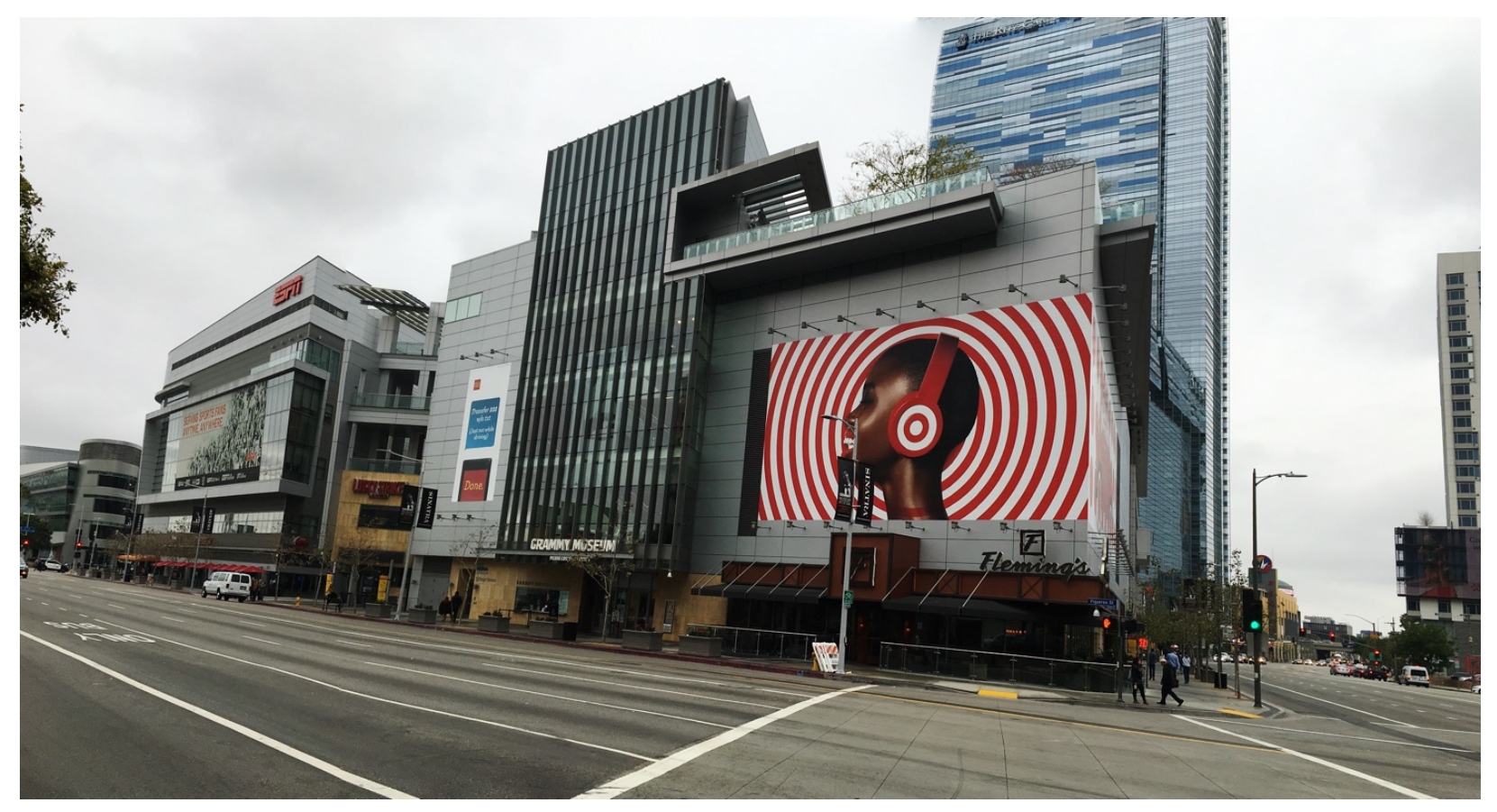

Figure 6: L.A. Live, Los Angeles. Photo by author.

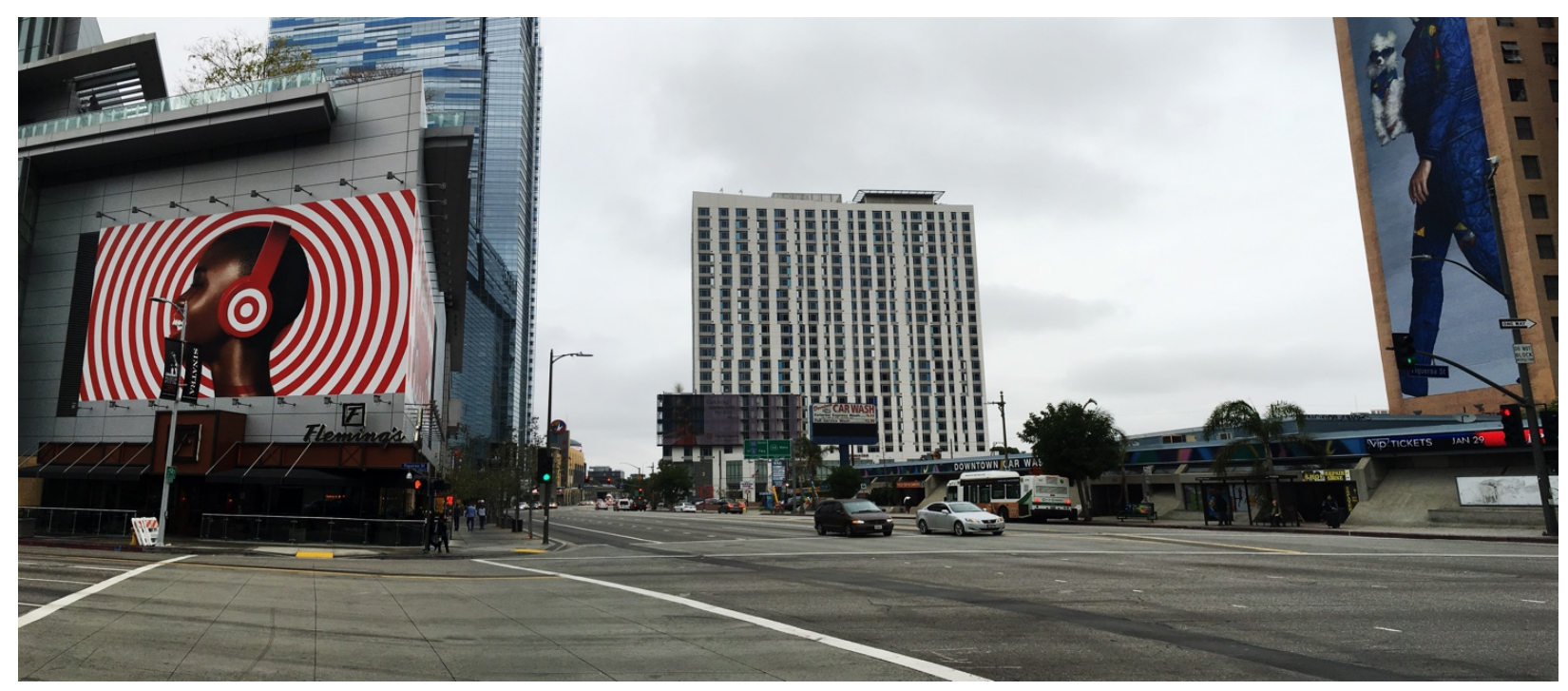

Figure 7: L.A. Live, Los Angeles. Photo by author.

As Marina Peterson observes, one of art's roles here was "masking social relations and power dynamics" with art acting as a kind of border which marked "inclusion and exclusion [regarding] efforts around housing, amenities, and galleries." These "have fixated on a divide between new residents and the homeless, granting authority, rights, and membership to some and not others." 75 Those to whom rights have accrued are those who "have substantial control of about a hundred acres in downtown Los Angeles. ${ }^{~} 76$ In a New Yorker profile of Tim Leiweke, CEO of L.A. Live's parent company, the cityscape that

\footnotetext{
${ }^{75}$ Marina Peterson, “Utopia/Dystopia: Art and Downtown Development in Los Angeles," Global Downtowns, 211, https://doi.org/10.9783/9780812208054.209.

${ }^{76}$ Connie Bruck, "The Man Who Owns L.A," New Yorker, January 16, 2012, accessed December 26, 2015, http://www.newyorker.com/magazine/2012/01/16/the-man-who-owns-l-a.
} 
preceded its construction was also imagined to be a Beale Street-like wasteland, entirely without human form or value:

Fifteen years ago, the area was an urban wasteland: thirty acres of flophouses, bars, strip clubs, and empty lots, forlornly situated near the 10 and 110 freeways. Now Leiweke can point to Staples Center, a twenty-thousand-seat arena, and to L.A. Live, a bustling entertainment district, which are almost entirely owned by A.E.G. Beneath flashing billboards advertising L.A. Live sponsors like Coca-Cola and Toyota, there are dozens of restaurants, a J.W. Marriott/Ritz-Carlton Hotel, the Nokia Theatre, the Grammy Museum, and a multiplex Regal Cinema. ${ }^{77}$

The developments spoke for themselves and the same patterns of public subsidy and private gain noted above were repeated here. Further, despite a much heralded Community Benefits Agreement (CBA) negotiated between community groups and the dominant parties, the same racially and economically exclusionary patterns of dual development played out in Los Angeles as they have in Seattle and Memphis, with the outcome producing once again, "a more stratified and segregated urban space." 78 As Marquardt and Fuller argue, the "new modes of social control accompanying the "urban renaissance" and the continuing privatization of inner cities" have proved as effective as the old. Further, these strategies of urban development "in effect steer possible political efforts away from dealing with the structural causes of social tensions. The efforts instead concentrate on a surface beautification."79

The gentrification of downtown Los Angeles has reproduced the most common outcomes of the dual development pathway in which international markets of investors and tourists are courted at the expense of the social development of those communities most directly affected by the developments. The focus on tourism, real estate, and construction has confronted working-class and poor residents of downtown with the strains of trying to afford increased rents on a dwindling number of inexpensive places to live. This in part exacerbated a rise in homelessness which grew into enough of a crisis to attract the attention of United Nations Human Rights Council who sent its envoy, Richard Alston to investigate; his response was highly critical. ${ }^{80}$ Yet despite the actual exclusion, displacement and stratification, The Grammy Museum is presented to the public as one of a whole collection of vibrant anthropological spaces in downtown. It is sold as open, inclusive, interactive experience that act as a place of social inclusion, while still symbolically anchoring and physically intertwined with the non-place of LA Live and its powerful exclusions. The Grammy Museum's handbills, pamphlets and ads exhort us to "Visit Music" and "record with famous producers and songwriters" while using music "as a gateway to learning, inspiring and cultivating creativity, critical thinking and self-expression." ${ }^{81}$ Similarly, L.A. Live was sold as "Times Square West" and "the centerpiece of a rejuvenated downtown" that had the power to bring the city center's "old movie houses, art deco buildings, thriving fashion and jewelry districts, open-air markets and performing arts centers" back to some form of a life worth living. ${ }^{82}$ Both attractions are enclosed in forms

\footnotetext{
${ }^{77}$ Bruck, "The Man Who Owns L.A."

${ }^{78}$ Daniel Wu, "Reimagining and Restructuring the Figueroa Corridor, 1990-2005: Growth Politics, Policy and Displacement," Race, Gender and Class 19, no. 1/2 (2012): 244-65; Michael Bader, "LA Is Resegregating-and Whites Are a Major Reason Why," Los Angeles Times, April 1, 2016, accessed April 14, 2016, http://www.latimes.com/opinion/op-ed/la-oebader-resegregation-los-angeles-20160401-story.html.

${ }^{79}$ Nadine Marquardt and Henning Füller, "Spillover of the Private City: BIDs as a Pivot of Social Control in Downtown Los Angeles," European Urban and Regional Studies 19, no. 2 (2012): 164, https://doi.org/10.1177/0969776411420019.

${ }^{80}$ Gale Holland, "U.N. monitor on extreme poverty tours skid row in L.A.," Los Angeles Times, December $11,2017$.

${ }^{81}$ Grammy Museum, School Tours and Educational Programs (Los Angeles: Grammy Museum, 2011/12).

${ }^{82}$ Beth Barrett, “Coming to Life," Los Angeles Daily News, September 14, 2001, N1; Michael Martinez, "L.A. Story: It's Time
} 
of experience-made material called Downtown, "the most historical, multilayered and fascinating part of Los Angeles," a place where "contractors are busy flipping historic buildings into condos, new galleries are luring patrons, and trendy restaurants and bars are turning on the lights." Downtown's "bump-and-nudge vitality isn't to be missed." 83

It is worth briefly examining the markedly similar patterns of dual development in major cities that have also been implemented in the UK. Interestingly, however, the museums examined here are linked to one another in unexpected ways. The British Music Experience, which was originally housed in the O2 Dome in London until 2014, and The Beatles' Story, set in the Albert Docks in Liverpool, are both parts of ongoing, multi-decade, multi-billion-pound redevelopments of two districts whose transformations are mind-bendingly expansive and expensive. Both follow the dual development model and, in each case, music museums are only tiny bits of glittery attraction whose confected advertised image is far more impressive than their actual presence. Further, their appearance and connotations have been used to smooth the way for the much larger and more lucrative schemes that followed. These music museums formed small, not overly successful parts of much larger schemes to transform these areas in their totality.

The O2 Dome, original home of the British Music Experience, stands as an appropriately crass monument to the distinct brand of old Tory and New Labour profligacy that fell under the euphemism "public-private partnership." Born as the Millennium Dome, the building developed as a kind of World Expo housing the so-called "Millennium Experience" exhibits. It fell into serious financial problems almost immediately after its opening when the anticipated annual flood of 12 million visitors did not appear. As The Economist noted, somewhat disingenuously, many thought it a suitable "metaphor for the whole New Labour project: a large, grandiose exterior was commissioned, and only afterwards did anyone think about what to put inside it." ${ }^{" 44}$ The building was sold for a fraction of its cost and was eventually turned into a well-liked music venue comfortingly enclosed by a shopping mall. As in downtown Los Angeles, a huge parcel of the Greenwich Peninsula has since been ceded to a single developer to implement a 25-year masterplan to develop one of the biggest and most luxurious housing developments in the UK. ${ }^{85}$ As the larger redevelopment project emerged, the exterior of Thames-side location of Greenwich was increasingly pierced with surveillance cameras and public art projects, both necessary pieces of infrastructure for developments in their larval stage.

When the BME was in residence at the $\mathrm{O} 2$, the path from the Tube station to the interior of the O2 Dome was traced by a very long, blandly populist timeline of British music, the ecstatic faces of each purported "generation" of musical revelers enticing you to become one of them if you weren't already. The faces of music fans like us confronted visitors in genre appropriate facial expressions and clothing. (Figures 8 and 9) Upon entering the building, you enter a circular shopping mall, providing a perceptually engulfing ring of amenities around the well-used, high-profile performance arena.

to Give Downtown Its Due," Oakland Tribune, May 20, 2007, $1+$.

${ }^{83}$ Downtown Los Angeles: Keep It In Your Pocket (Footscray, Victoria: Lonely Planet, 2008), n.p.

84 "Inside Blair's big tent: More than half the British public think it was wrong to build the Millennium Dome. Will this damage the government?," The Economist, January 8, 2000, 53. It should be noted that the project began before Labour won power in 1997.

${ }^{85}$ Dave Hill, "What Next for the Greenwich Peninsula?," The Guardian, January 27, 2015, accessed December 26, 2015, http://www.theguardian.com/uk-news/davehillblog/2015/jan/26/ what-next-for-the-greenwich-peninsula; Heather Thompson, "Greenwich Peninsula Apartments: First Look," The Telegraph, April 10, 2015, accessed December 26, 2015, http://www.telegraph.co.uk/luxury/design/67575/tom-dixon-designs-the-first-apartments-for-greenwich-peninsula.html. 


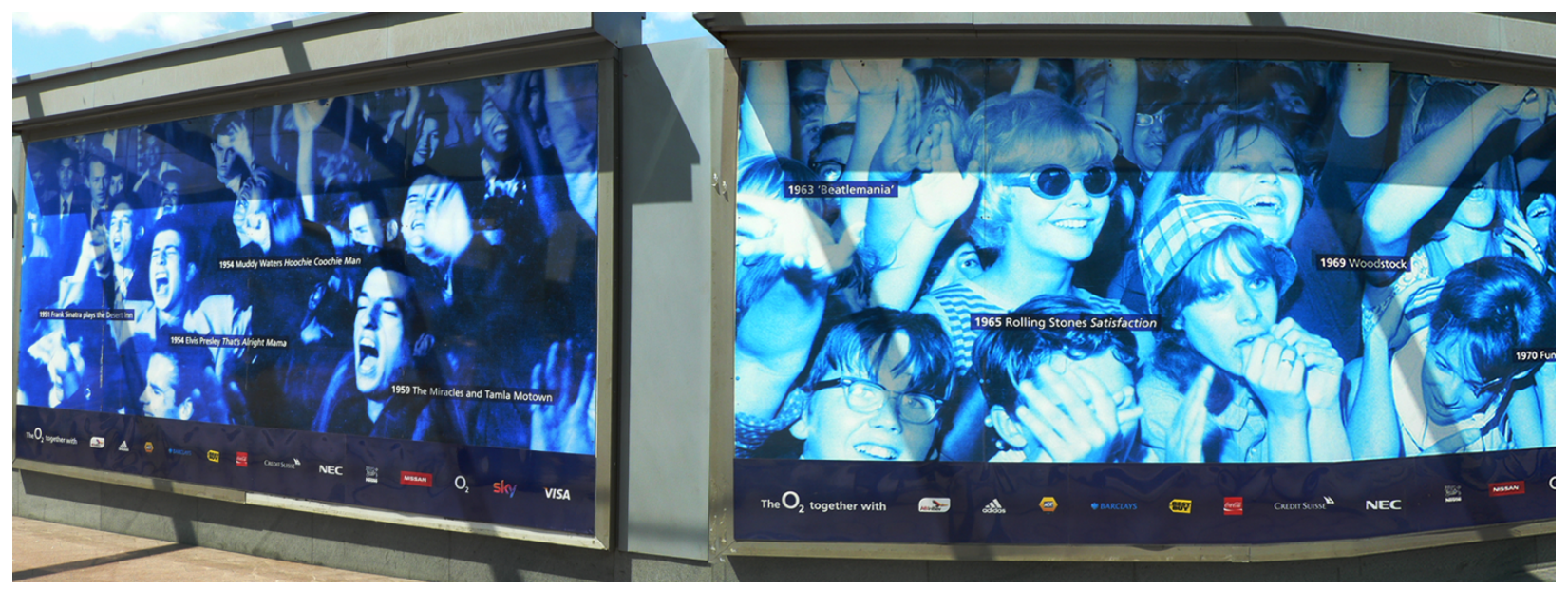

Figure 8: British Music Experience ads, Greenwich. Photo by author.

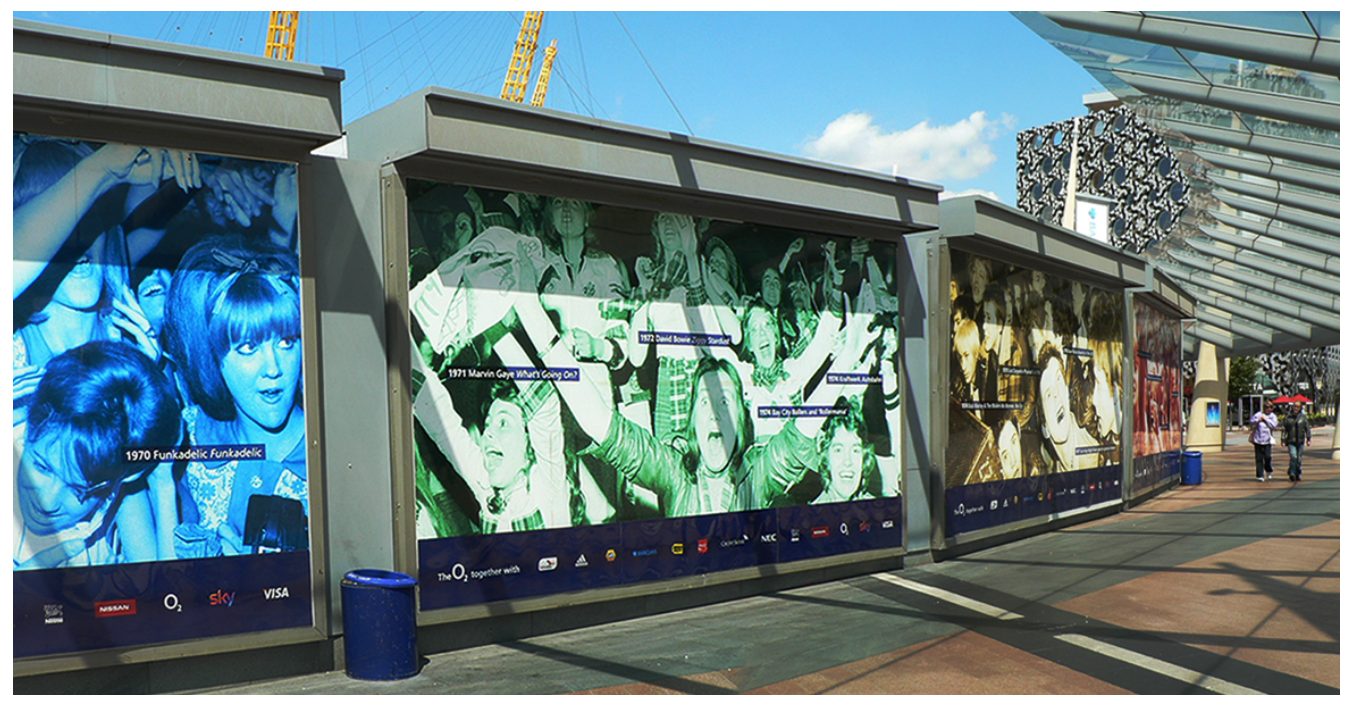

Figure 9: British Music Experience ads, Greenwich. Photo by author.

The BME itself was slotted into a comparatively small space tucked away above the ground level. The walk there presented visitors with fairly cheap impermanent cardboard ads to lead you in the right direction. The BME hardly had pride of place inside the building, despite the extensive hoardings devoted to "the music" outside. The BME was housed here for five years before its move to that other capital of British music, Liverpool.

Liverpool, too, bears the sharp marks of the ongoing transformation of its waterfront and extensive docks areas. This sprawling district links the City Centre to the waterfront through the sleek, privately owned Liverpool One shopping area and chunky, brick-laden, past renown of the Albert Dock complex, home of The Beatles' Story museum. (Figure 10) The regeneration of these substantial parts of the city have been claimed to be at least in part the result of the so-called "Liverpool model" that has produced what Cox and O'Brien call "a wider narrative of how British cities can develop and respond to the continued challenges of deindustrialization and global competition" by linking urban regeneration to culture and creative industries. ${ }^{86}$ But despite such tags, Liverpool has followed the dual development

${ }^{86}$ Tamsin Cox and Dave O’Brien, "The "Scouse Wedding” and Other Myths: Reflections on the Evolution of a 'Liverpool 
model in the same way as the other cities examined here. And the champions of this model also presumed that focusing on tourism and real estate through the attractions of the "creative industries" through public subsidy would acquire both the investment capital to support high tech industry and the desirable demographic of those who work in these industries as residents. As Connolly explains,

within the UK, this approach, fostered by the ruling New Labour party, matched its much heralded "Third Way" politics, in that it seemed to offer a "post-ideology", politically appealing rapprochements between antithetical concepts: art/culture; social justice/economic development and city centre boosterism/community development. ${ }^{87}$

The arrival of The Museum of Liverpool in 2011 and the International Slavery Museum in 2007 filled out an extraordinary range of the similar amenities of the type the expected "post-ideological" residents should be expected to crave.

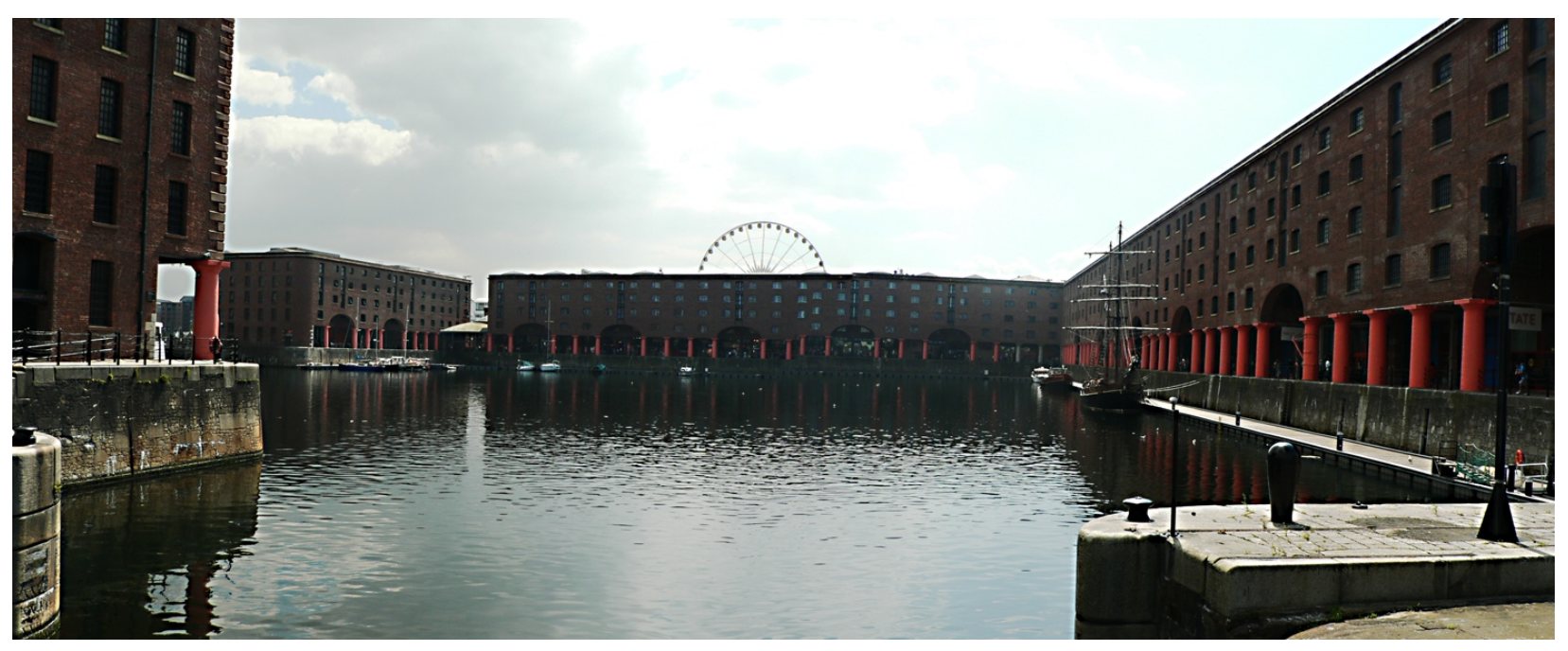

Figure 10: Albert Docks. Liverpool. Photo by author.

The more consequential recent policy development, however, was the granting of the Mersey Waters Enterprise Zone in 2011. Covering two broad areas on either side of the River Mersey, the zone offers substantial tax breaks and infrastructure subsidies to businesses that relocate there. Of particular relevance is the recently approved Liverpool Waters project that will spread across the entire waterfront area, "a development at the scale of Canary Wharf and designed like Dubai, covering 60 hectares with clusters of skyscrapers and 1.7 million sq metres of offices, homes and shopping." ${ }^{88}$ Like the forty-two acres of the City Centre given over to Liverpool One, Liverpool Waters is also private. It will contribute to an unbroken expanse of private property that will stretch from Liverpool One, past the Albert Docks and all the way up to the Prince's Docks at the north end of the waterfront. The jumble of material that confronted visitors on Liverpool's waterfront for years has gradually being cleared and flattened to make way for what amounts to an entirely new waterfront district. (Figure 11)

Model' for Culture-Led Urban Regeneration," Cultural Trends 21, no. 2 (2012): 94, https://doi.org/10.1080/09548963.2012.674749.

${ }^{87}$ Mark Connolly, 'The "Liverpool Model(s)': Cultural Planning, Liverpool and Capital of Culture 2008," International Fournal of Cultural Policy 19, no. 2 (2013):164-8, https://doi.org/10.1080/10286632.2011.638982.

${ }^{88}$ Mark Smith, "Liverpool Waters Redevelopment Gets Government Green Light," The Guardian, March 6, 2013, accessed

December 26, 2015, http://www.theguardian.com/uk/2013/mar/05 /liverpool-waters-redevelopment-green-light. 


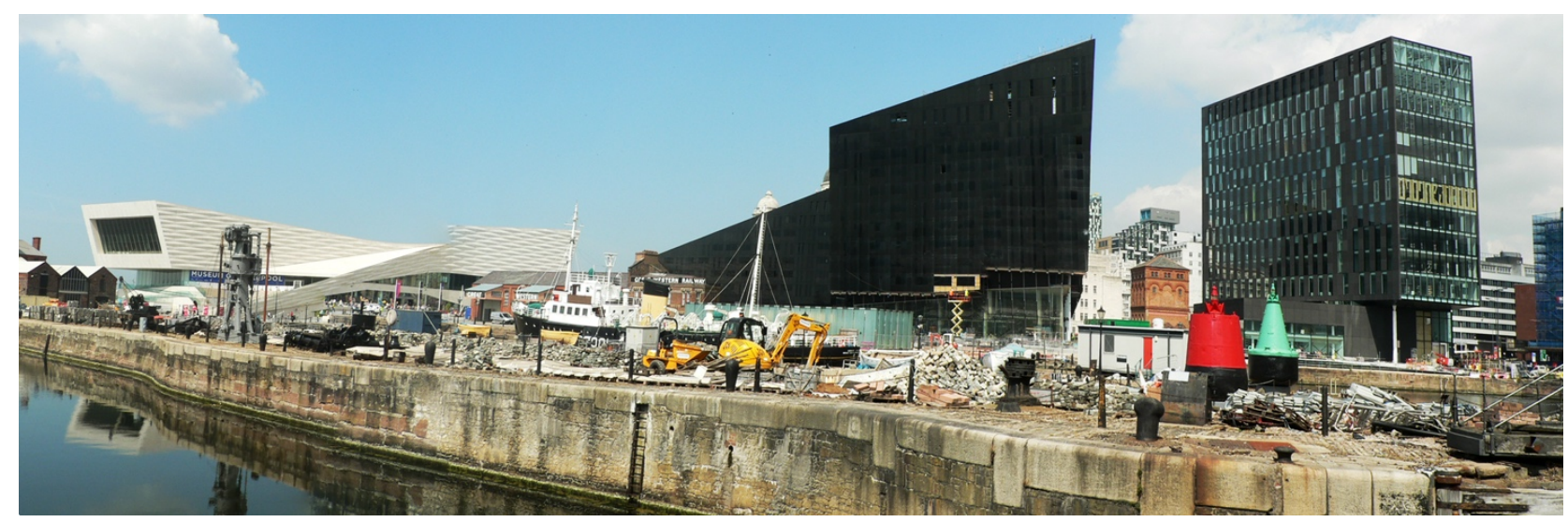

Figure 11: Waterfront, Liverpool. Photo by author.

Arguably, Liverpool Waters brings to a massive head the processes so strongly boosted during Liverpool's European City of Culture year in 2008 which helped pave the way for the enterprise zone and the redevelopment plans which have handed over the majority of the city's defining waterfront district to a private development company. The Liverpool Model has proved itself to be a comparatively acceptable way to push public resources into private hands. The perceptual change, at least, has been significant, as Cox and O'Brien explain:

Perhaps the most significant—and widely reported, though not universally felt-element of success was the apparent corollary around morale, confidence and perceptions, particularly in relation to the city itself. Press coverage changed significantly in both tone and focus, national surveys showed improvements in public perceptions, and visitors felt safer, enjoying the overall atmosphere and welcome and rating Liverpool better than previously against other cities. ${ }^{89}$

As with the other examples noted here, intangible benefits such as improved civic morale and confidence accrued to a broadly construed "public," while the perhaps more tangible benefits accrued to other parties, especially those privatized for the use of businesses and affluent residents. Meanwhile, the Liverpool City Council has discovered what other cities who have followed the nostrums of dual development have discovered. As of 2015 , it projected that it was likely that it would no longer be able to fund even the most basic services by $2018 .^{90}$

\section{Conclusion}

One of the primary ways of analyzing and explaining the range of developments examined here has been through the many extremely influential theses on the relationship between the arts sector and urban renewal. ${ }^{91}$ Much of this body of work claims that the economic shift to an age defined and dominated by

\footnotetext{
${ }^{89}$ Cox and O’Brien, 96.

${ }^{90}$ Liam Murphy, “Meltdown is imminent': Liverpool council may not be able to fund even basic services by 2018," Liverpool Echo, September 22, 2015, accessed December 26, 2015, http:/www.liverpoolecho.co.uk/news/ liverpool-news/meltdownimminent-liverpool-council-not-10101627.

${ }^{91}$ Richard Florida, The Rise of the Creative Class: And How It's Transforming Work, Leisure, Community and Everyday Life (New York: Basic Books, 2002); Sharon Zukin, "Changing Landscapes of Power: Opulence and the Urge for Authenticity," International Fournal of Urban and Regional Research 33, no. 2 (2009): 543-53, https://doi.org/10.1111/i.14682427.2009.00867.x; Sharon Zukin, The Culture of Cities (Cambridge, MA: Blackwell, 1995); Anne Cronin and Kevin
} 
technology and information has produced a dominant "creative class" of powerful people whose demands don't stop at self-enrichment, but extend to living an authentic and psychologically rewarding life, uniquely attuned to the equitable treatment of others. This in turn means that cities become the defining centers of creativity and innovation that have made the places that host them most amenably safer, more prosperous, and more diverse. ${ }^{92}$ However, the methods, measures, and results of this new form of urbanism are at best suspect and circularly self-satisfying. ${ }^{93}$ As scholars such as Aaron Schneider and Jamie Peck have shown, the tangible results of the models of dual development and the creative classes have not proved the economic successes many thought them to be. As Peck argues, "rather than "civilizing" urban economic development by "bringing in culture," creativity strategies do the opposite: they commodify the arts and cultural resources, even social tolerance itself, suturing them as putative economic assets to evolving regimes of urban competition." 94 Further, he claims, the creative class thesis is "predicated on, and designed for, neoliberalized terrain. Repackaging urban cultural artifacts as competitive assets, they value them (literally) not for their own sake, but in terms of their (supposed) economic utility. In order to be enacted, they presume and work with gentrification, conceived as a positive urban process." 95 One of the main outcomes of this brand of urban redevelopment has been the normalization of "flexible labormarket conditions, lionizing a class of workers that can not only cope with, but positively revel in, this environment of persistent insecurity and intense, atomized competition." ${ }^{96}$

The museums I've examined here bear a few important characteristics that mirror the defining facets of dual development exhibited by the power brokers who created the slots into which they have been set. Each museum has based its institutional legitimacy on the appropriation of the affective labor of the musicians and listeners whose agency they have sought to display in their collections and exhibitions. These museums have done this through the continuing collection and display of a huge range of aural, visual, and material artifacts. This inevitably results in the imposition of some kind of institutional imprimatur on the music's circulation and its meaning. The most important mediating influence found throughout all the music museums studied here is the imputation of an originating and persistent demos to their subjects, an imputation that simply doesn't stand up to serious scrutiny if we wish to consider these institutions as more than merely a collection of famous objects.

When we do this, we find another less comforting story. We find institutions that display the vernacular materials of popular music and culture in contexts defined by "the physical manifestations of synthetically conceived identities transposed onto synthetically conceived places, demarcating culturally independent sites where corporate value systems materialize into physical territories." ${ }^{97}$ The displays found inside these popular music museums repeatedly present a universal demos of which we are already expected to be a part, a demos only made possible through "the music." However, these museums are not simply organizing systems for sets of cultural symbols that are intended merely to "disguise the instrumental exchange" that is also at the heart of this demos; in short, they do not appear as simply

Hetherington, Consuming the Entrepreneurial City: Image, Memory, Spectacle (New York: Routledge, 2008).

92 Florida, 287-9.

${ }^{93}$ Jamie Peck, "Struggling with the Creative Class," International Fournal of Urban and Regional Research 29, no. 4 (2005): $744-$

5, https://doi.org/10.1111/i.1468-2427.2005.00620.x.

${ }_{94}$ Peck, 763.

${ }^{95}$ Peck, 764.

${ }^{96}$ Peck, 764-5.

${ }^{97}$ Anna Klingmann, Brandscapes: Architecture in the Experience Economy (Cambridge, MA: The MIT Press, 2007$), 83$. 
"another relation between [a] commercial place and a consumer." ${ }^{98}$ Instead, we are asked to exchange our time and attention for something more familiar and meaningful. "The music," much like "the fun" or "the pleasure" these urban districts promise and provide, makes these socially and politically consequential conglomerations of material and economic power feel far more immediately and subtly enervating than they might otherwise. As a result, they become far more intimately affecting and personally eloquent than any mere conglomeration of bricks, glass, chrome, and conceit could. It is this crucial, if not defining aspect of these institutions that needs far greater attention. For what we are meant to experience inside these places in some significant way dependent on forces pervasively in evidence outside. While thoroughly shaping and defining these places, the power that makes them, and makes them sensually satisfying, remains outside, excluded, without any immediate, apparent, or necessary expression inside.

\section{Bibliography}

Abbott, Carl. The New Urban America: Growth and Politics in Sunbelt Cities. Chapel Hill: University of North Carolina Press, 1981.

Allyn, Bobby. "Nashville Gambles on Lure of New Convention Center," New York Times, November 20, 2012, B8.

Atwood, Brett. "Music Museum Due: Online Exhibit Bows," Billboard 111 (1999): 1, 78. Associated Press. "Debt-ridden Seattle Center Drains City Funds," Columbian, November 8, 2004, C4.

Augé, Marc. Non-Places: An Introduction to an Anthropology of Supermodernity. London: Verso, 1995.

Bader, Michael. "L.A. Is Resegregating-and Whites Are a Major Reason Why," Los Angeles Times, April 1, 2016. Accessed April 14, 2016. http://www.latimes.com/opinion/op-ed/la-oe-bader-resegregation los-angeles-20160401-story.html.

Ballantyne, Roy, and David Uzzell. "Looking Back and Looking Forward: The Rise of the Visitor Centered Museum.” Curator: The Museum Journal 54, no. 1 (2011): 85-92.

https://doi.org/10.1111/j.2151-6952.2010.00071.x.

Barrett, Beth. "Coming to Life," Los Angeles Daily News, September 14, 2005, N1.

Bennett, Andy. “'Heritage Rock': Rock Music, Representation and Heritage Discourse.' Poetics 37, no. 5 6 (2009): 479-489. https://doi.org/10.1016/j.poetic.2009.09.006.

Bennett, Tony. "Civic Seeing: The Museum and the Organization of Vision." In A Companion to Museum Studies, edited by Sharon Macdonald, 263-281. Malden, MA: Blackwell, 2006. https://doi.org/10.1002/9780470996836.ch16.

Bennett, Tony. "Exhibition, Difference, and the Logic of Culture.” In Museum Frictions: Public Cultures/Global Transformations, edited by Ivan Karp, et al., 46-69. Durham, NC: Duke University Press, 2006. https://doi.org/10.1215/9780822388296-003.

Bennett, Tony. The Birth of the Museum: History, Theory, Politics. New York: Routledge, 1995.

Bergengren, Charles. "Simply Contradictory: The Rock and Roll Hall of Fame and Museum." Journal of American Folklore 112, no. 446 (1999): 544-550. https://doi.org/10.2307/541492.

Berger, Knute. "Seattle Center: How the city bulldozed history to create change," Crosscut, May 19, 2011. Accessed September 18, 2015. http://crosscut.com/2011/05/seattle-center-how-city-bulldozed

\footnotetext{
${ }^{98}$ Gottdiener, 73.
} 
history-create-c/.

Biles, Roger. "Epitaph for Downtown: The Failure of City-Planning in Post-World War Two Memphis." Tennessee Historical Quarterly 44, no. 3 (1985): 267-84.

Born, Georgina. "On Musical Mediation: Ontology, Technology and Creativity." Twentieth-Century Music 2, no. 1 (2005): 7-36. ttps://doi.org/10.1017/S147857220500023X.

Brabazon, Tara, and Stephen Mallinder. "Popping the Museum: The Cases of Sheffield and Preston." Museum and Society 4, no. 2 (2006): 96-112.

Brandellero, Amanda, and Susanne Janssen. "Popular Music as Cultural Heritage: Scoping Out the Field of Practice.” International Journal of Heritage Studies 20, no. 3 (2014): 224-40. https://doi.org/10.1080/13527258.2013.779294.

Brownell, Blaine. "The Commercial-Civic Elite and City Planning in Atlanta, Memphis, and New Orleans in the 1920s." The Journal of Southern History 41, no. 3 (1975): 339-368.

https://doi.org/10.2307/2206403.

Bruce, Chris. "Spectacle and Democracy: Experience Music Project as a Post-Museum." In New Museum Theory and Practice: An Introduction, edited by Janet Marstine, 129-51. Malden, MA: Blackwell, 2006. https://doi.org/10.1002/9780470776230.ch5.

Bruck, Connie. “The Man Who Owns L.A.,” New Yorker, January 16, 2012. Accessed December 26, 2015. http://www.newyorker.com/magazine/2012/01/16/the-man-who-owns-l-a.

Connolly, Mark. "The "Liverpool Model(s)": Cultural Planning, Liverpool and Capital of Culture 2008." International Journal of Cultural Policy, 19 (2013): 162-81. https://doi.org/10.1080/10286632.2011.638982.

Canadian Press. "At 50th Anniversary of World's Fair, Seattle Center Continues to Evolve," The Brandon Sun, June 16, 2012. Accessed September 18, 2015. http://www.brandonsun.com/weekend/at-50th anniversary-of-worlds-fair-seattle-center-continues-to-evolve-159248685.html?thx=y.

Country Music Hall of Fame and Museum. A Visitor's Companion. Nashville, TN: Country Music Foundation, 2004.

Cox, Tamsin, and Dave O’Brien. "The "Scouse Wedding” and Other Myths: Reflections on the Evolution of a 'Liverpool Model' for Culture-Led Urban Regeneration.” Cultural Trends 21, no. 2 (2012): 93 101. https://doi.org/10.1080/09548963.2012.674749.

Cronin, Anne, and Kevin Hetherington, eds. Consuming the Entrepreneurial City: Image, Memory, Spectacle. New York: Routledge, 2008.

Davis, Mike, and Daniel Bertrand Monk, eds. Evil Paradises: Dreamworlds of Neoliberalism. New York: New Press, 2007.

Downtown Los Angeles: Keep It In Your Pocket. Footscray, Victoria: Lonely Planet, 2008.

Eskenazi, Stuart. "City to spend up to $\$ 650 \mathrm{~m}$ on Seattle Center revamp," The Vancouver Sun, February 27, 2008, B2.

Experience Music Project. the experience. Seattle: Experience Music Project, 2000.

Experience Music Project. the building. Seattle: Experience Music Project, 2000.

Experience Music Project. Crossroads: The Experience Music Project Collection. Seattle: Experience Music Project, 2000.

Fairchild, Charles. Danger Mouse's The Grey Album. New York: Bloomsbury Academic, 2014. https://doi.org/10.5040/9781501305962.

Fairchild, Charles. "Popular Music," In The Cultural Intermediaries Reader, edited by Maguire, Jennifer 
S., and Julian Matthews, 125-33. London: SAGE, 2014.

https://doi.org/10.4135/9781473912281.n12.

Fairchild, Charles. Music, Radio and the Public Sphere: The Aesthetics of Democracy. Basingstoke, UK:

Palgrave, 2012. https://doi.org/10.1057/9780230390515.

Findlay, John. "The Off-Center Seattle Center: Downtown Seattle and the 1962 World's Fair." The

Pacific Northwest Quarterly 80, no. 1 (1989): 2-11.

Florida, Richard. The Rise of the Creative Class: And How It's Transforming Work, Leisure, Community

and Everyday Life. New York: Basic Books, 2002.

Fricke, David. “The \$240 Million Temple of Rock: Paul Allen's Experience Music Project Opens in

Seattle," Rolling Stone, July 6-20, 2000, 41, 48.

George-Warren, Holly. The Rock and Roll Hall of Fame: The First 25 Years. New York: Collins Design, 2009.

Gibson, Chris, and John Connell. "Music, Tourism and the Transformation of Memphis," Tourism

Geographies 9, no. 2 (2007): 160-90. https://doi.org/10.1080/14616680701278505.

Gold, Noe. "Experience This," Hollywood Reporter, June 13, 2000, 23.

Gottdiener, Mark. The Theming of America: Dreams, Media Fantasies, and Themed Environments.

Boulder, CO: Westview Press, 2001.

Graham, Beryl, and Sarah Cook. Rethinking Curating: Art After New Media. Cambridge, MA: The MIT

Press, 2010.

Grammy Museum. School Tours and Educational Programs. Los Angeles: Grammy Museum, 2011/12.

Greenhalgh, Paul. "Education, Entertainment and Politics: Lessons from the Great International

Exhibitions.” In The New Museology, edited by Peter Vergo, 74-98. London: Reaktion Books, 1989.

Griffiths, Alison. Wondrous Difference: Cinema, Anthropology and Turn-of-the-Century Visual Culture.

New York: Columbia University Press, 2002.

Henning, Michelle. Museums, Media and Cultural Theory. Maidenhead, UK: Open University Press, 2006.

Hennion, Antoine. "Music and Mediation: Toward a New Sociology of Music," In The Cultural Study of

Music: A Critical Introduction, edited by Martin Clayton et al., 80-91. London: Routledge, 2003.

Hetherington, Kevin. Capitalism's Eye: Cultural Spaces of the Commodity. New York: Routledge, 2007.

Hill, Dave. "What Next for the Greenwich Peninsula?," The Guardian, January 27, 2015. Accessed

December 26, 2015. http://www.theguardian.com/uk-news/davehillblog/2015/jan/26/ what-next-for the-greenwich-peninsula.

Hooper-Greenhill, Eilean. Museums and the Interpretation of Visual Culture. London: Routledge, 2000.

Huyssen, Andreas. Twilight Memories: Marking Time in a Culture of Amnesia. New York: Routledge, 1995.

"Inside Blair's big tent: More than half the British public think it was wrong to build the Millennium

Dome. Will this damage the government?” The Economist, January 8, 2000, 53.

Johansson, Ola. “Ten People Can't Run this City Anymore: Neoliberalism and Governance Change in

Nashville, Tennessee." Southeastern Geographer 47, no. 2 (2007): 298-319.

https://doi.org/10.1353/sgo.2007.0028.

Karp, Ivan, et al. Museum Frictions: Public Cultures/Global Transformations. Durham, NC: Duke

University Press, 2006. https://doi.org/10.1215/9780822388296. 
Kelleher, Susan, and Emily Heffter. "Goodbye to grand plan for Seattle Center?” Seattle Times, March 17, 2010. Accessed April 3, 2010. http://www.seattletimes.com/seattle-news/goodbye-to-grand-plan for-seattle-center/.

Kirshenblatt-Gimblett, Barbara. "Exhibitionary Complexes," In Museum Frictions: Public Cultures/Global Transformations, edited by Ivan Karp, et al., 35-45 Durham, NC: Duke University Press, 2006. https://doi.org/10.1215/9780822388296-002.

Klingmann, Anna. Brandscapes: Architecture in the Experience Economy. Cambridge, MA: MIT Press, 2007.

Knell, Simon, Suzanne MacLeod and Sheila Watson, eds. Museum Revolutions: How Museums Change and Are Changed, London: Routledge, 2007.

Leonard, Marion. "Exhibiting Popular Music: Museum Audiences, Inclusion and Social History.” Journal of New Music Research 39, no. 2 (2010): 171-81. https://doi.org/10.1080/09298215.2010.494199.

Leonard, Marion. "Constructing Histories Through Material Culture: Popular Music, Museums and Collecting." Popular Music History 2, no. 2 (2007): 147-67. https://doi.org/10.1558/pomh.v2i2.147.

Lloyd, Richard. "East Nashville Skyline.” Ethnography 12, no. 1 (2011): 114-45. https://doi.org/10.1177/1466138110387219.

Lloyd, Richard, and Brian D. Christens. "Reaching for Dubai: Nashville Dreams of a Twenty-First Century Skyline.” In Global Downtowns, edited by Marina Peterson and Gary McDonogh, 113 353. Philadelphia: University of Pennsylvania Press, 2012.

https://doi.org/10.9783/9780812208054.113.

Marquardt, Nadine, and Henning Füller. "Spillover of the Private City: BIDs as a Pivot of Social Control in Downtown Los Angeles." European Urban and Regional Studies 19, no. 2 (2012): 153-66. https://doi.org/10.1177/0969776411420019.

Martinez, Michael. "L.A. Story: It's Time to Give Downtown Its Due," Oakland Tribune, May 20, 2007, $1+$.

Memphis Travel. Memphis Map and Travel Guide. Memphis, TN: Memphis Travel, 2015.

McGuigan, Jim. Cool Capitalism. London: Pluto Press, 2009.

Message, Kylie. New Museums and the Making of Culture. Oxford, UK: Berg, 2006.

Message, Kylie. “The New Museum.” Theory, Culture and Society 23, no. 2-3 (2006): 603-6. https://doi.org/10.1177/0263276406023002110.

Morgan, Murray. Skid Road: An Informal Portrait of Seattle. New York: Viking Press, 1960.

Murphy, Liam. "'Meltdown is Imminent': Liverpool Council May Not Be Able to Fund Even Basic Services by 2018," Liverpool Echo, September 22, 2015. Accessed on December 26, 2015. http://www.liverpoolecho.co.uk/news/liverpool-news/meltdown-imminent-liverpool-council-not 10101627.

"Nashville Convention Center Controversy Not Over." Saving Country Music. Last modified August 28, 2010. http://www.savingcountrymusic.com/nashville-convention-center-controversy-not-over.

Nashville Visitor Guide. Nashville, TN: Nashville Convention and Visitor's Bureau, 2015. Negus, Keith. "The Work of Cultural Intermediaries and the Enduring Difference Between Production and Consumption," Cultural Studies 16, no. 4 (2002): 501-15. https://doi.org/10.1080/09502380210139089.

Peck, Jamie. "Struggling with the Creative Class," International Journal of Urban and Regional Research 29, no. 4 (2005): 740-70. https://doi.org/10.1111/j.1468-2427.2005.00620.x. 
Peterson, Marina. "Utopia/Dystopia: Art and Downtown Development in Los Angeles." In Global

Downtowns, edited by M. Peterson and G. McDonogh, 209-33. Philadelphia: University of Pennsylvania Press, 2012. https://doi.org/10.9783/9780812208054.209.

Peterson, Marina, and Gary McDonogh. Global Downtowns. Philadelphia: University of Pennsylvania Press, 2012. https://doi.org/10.9783/9780812208054.

Prior, Nick. "Critique and Renewal in the Sociology of Music: Bourdieu and Beyond." Cultural Sociology 5, no. 1 (2011): 121-38. https://doi.org/10.1177/1749975510389723.

Reising, Russell. "The Secret Lives of Objects; The Secret Stories of Rock and Roll: Cleveland's Rock and

Roll Hall of Fame and Museum and Seattle's Experience Music Project.” American Quarterly 53, no. 3 (2001): 489-510. https://doi.org/10.1353/aq.2001.0027.

Retort. "Afflicted Powers: The State, the Spectacle and September 11." New Left Review 27 (2004): 5-21.

Roberts, Les, and Sara Cohen. "Unauthorising Popular Music Heritage: Outline of a Critical Framework." International Journal of Heritage Studies 20, no.3 (2014): 241-61.

https://doi.org/10.1080/13527258.2012.750619.

Rock and Roll Hall of Fame and Museum. The Rock Pack. New York: Universe Publishing, n.d.

Ross, Max. "Interpreting the New Museology." Museum and Society 2, no. 2 (2004): 84-103.

Russell, James S. “A Marriage of Money, Technology, Youth Culture, and Glitz.” Architectural Record 188, no. 8 (2000): 126-37.

Sandberg, Mark. Living Pictures, Missing Persons: Mannequins, Museums, and Modernity. Princeton,

NJ: Princeton University Press, 2003.

Saumarez Smith, Charles. "Museums, Artefacts, and Meanings." In The New Museology, edited by Peter Vergo, 6-21. London: Reaktion Books, 1989.

Seattle Center. Drawn to the Center: Seattle Center Century 21 Master Plan. Seattle, WA: Century 21

Committee, 2008.

Seattle World's Fair. Century 21 Exposition Guide, 1962. Accessed May 26, 2016.

http://digitalcollections.lib.washington.edu/cdm/compoundobject/collection/ptec/id/3769.

Silk, Michael L., and David L. Andrews. "Managing Memphis: Governance and Regulation in Sterile

Spaces of Play." Social Identities 14, no. 3 (2008): 395-414.

https://doi.org/10.1080/13504630802102820.

Smith, Mark. "Liverpool Waters Redevelopment Gets Government Green Light," The Guardian, March

6, 2013. Accessed December 26, 2015. http:/www.theguardian.com/uk/2013/mar/05/liverpool

waters-redevelopment-green-light.

Strauss, Neil. "Making a Museum Out of Music, Part 2," New York Times, June 26, 2000, E1+.

Thompson, Heather. "Greenwich Peninsula Apartments: First Look," The Telegraph, April 10, 2015,

Accessed December 26, 2015. http://www.telegraph.co.uk/luxury/design/67575/tom-dixon-designs

the-first-apartments-for-greenwich-peninsula.html.

Vergo, Peter. The New Museology. London: Reaktion Books, 1989.

Vishmidt, Marina. “The Mirror of the Network." In Uncorporate Identity, edited by Vinca Kruk and

Daniel van der Velden, 147-56, 553-62. Zurich: Lars Muller Publishers, 2010.

Ward, Getahn. "Office Tower, Entertainment Planned at Old Nashville Convention Center Site," The

Tennessean, December 4, 2013. Accessed December 28, 2015.

http://archive.tennessean.com/article/20131204/BUSINESS02/312040109/Office-tower

entertainment-planned-old-Nashville-Convention-Center-site. 
Witcomb, Andrea. Re-imagining the Museum: Beyond the Mausoleum. London: Routledge, 2003. https://doi.org/10.4324/9780203361023.

Wu, Daniel. "Reimagining and Restructuring the Figueroa Corridor, 1990-2005: Growth Politics, Policy and Displacement." Race, Gender and Class 19, no. 1/2 (2012): 244-65.

Zukin, Sharon. "Changing Landscapes of Power: Opulence and the Urge for Authenticity." International Journal of Urban and Regional Research 33, no. 2 (2009): 543-53. https://doi.org/10.1111/j.14682427.2009.00867.x.

Zukin, Sharon. The Cultures of Cities, Cambridge, MA: Blackwell, 1995. 